\title{
New Multicomponent Reaction for the Direct Synthesis of $\beta$-Aryl- $\gamma$-nitroesters Promoted by Hydrotalcite-Derived Mixed Oxides as Heterogeneous Catalyst
}

\author{
Caroline R. M. D'Oca, ${ }^{a}$ Fabricio F. Naciuk, ${ }^{a}$ Jéssica C. Silva, ${ }^{a}$ Esthéfani P. Guedes, ${ }^{a}$ \\ Celso C. Moro, ${ }^{b}$ Marcelo G. M. D'Oca, ${ }^{c}$ Leonardo S. Santos, ${ }^{d}$ Fabiane M. Natchigalle \\ and Dennis Russowsky*a
}

${ }^{a}$ Laboratório de Sinteses Orgânicas and ${ }^{b}$ Laboratório de Sólidos e Superfícies, Instituto de Química, Universidade Federal do Rio Grande do Sul, Av. Bento Gonçalves 9500, 91501-970 Porto Alegre-RS, Brazil

'Laboratório Kolbe de Síntese Orgânica, Escola de Química e Alimentos, Universidade Federal do Rio Grande, Av. Italia, km 08, Rio Grande-RS, Brazil

${ }^{d}$ Laboratory of Asymmetric Synthesis, Chemistry Institute of Natural Resources Universidad de Talca, 2 Norte 685, Talca, Chile

\author{
${ }^{e}$ Nanobiotechnology Division at University of Talca, Fraunhofer Chile Research Foundation, \\ Center for Systems Biotechnology, PO Box 747, Talca, Chile
}

\begin{abstract}
A new approach based on multicomponent/domino combined reactions for the synthesis of $\gamma$-nitroesters promoted by a mixed aluminium-magnesium oxides derived from hydrotalcite-like material was developed. Different $\gamma$-nitroesters were synthesized in 15-95\% yield using Meldrum's acid, aromatic aldehydes, nitromethane and different alcohols as reagents and solvents. The $\gamma$-aminobutyric acid derivatives, Phenibut and Baclofen, were prepared in 63 and $61 \%$ overall yield, respectively, through a two steps synthetic strategy. A mechanistic pathway was proposed based on the gas chromatography mass spectrometry (GC-MS) and electrospray ionization mass spectrometry (ESI-MS) experiments.
\end{abstract}

Keywords: GABA, baclofen, mixed Al-Mg oxides, hydrotalcite, multicomponent, domino

\section{Introduction}

Gamma aminobutyric acid (GABA) and $L$-glutamic acid are the two major neurotransmitters that regulate neuronal activity in the brain. While $L$-glutamic acid is a neurotransmitter that induces an excitatory effect, GABA acts as the major inhibitory neurotransmitter. ${ }^{1}$

The widespread presence of GABA and $L$-glutamic acid in the brain is related to various functions of the central nervous system (CNS), including novice chemical abuse disorders, making them two of the most promising targets for the development of neuropsychiatric drugs. ${ }^{2}$ Due to their fundamental role in neurotransmission, these systems are involved in a range of commercially available drugs, such as Phenibut, Baclofen, Gabapentin, and Pregabalin. ${ }^{3}$

Multicomponent reactions (MCRs) have been used as a versatile synthetic method for the preparation of complex

*e-mail: dennis@iq.ufrgs.br molecules from available starting materials via a single pathway. ${ }^{4}$ MCRs have unique advantages, such as a high bond-forming efficiency, simple and short procedures, a high level of atomic economy and low impact on the environment. ${ }^{5-7}$

The structural simplicity of Meldrum's acid (1), combined with its unique properties, has made this a versatile reagent in organic syntheses, especially those based on the multicomponent process. ${ }^{8-10}$ In addition, the design and development of environment-friendly catalysts have been the subject of intense research. ${ }^{11}$

The hydrotalcite like compounds (HT), also known as layered double hydroxides (LDH), are anionic clay materials that have been extensively investigated as heterogeneous base catalysts. ${ }^{12-15}$ The HT-like compounds exhibit dual basic/acid properties ${ }^{16,17}$ and can be useful as bifunctional catalysts in different organic transformations. ${ }^{18,19}$

As a part of our ongoing efforts in the field of $\mathrm{MCR},{ }^{20-24}$ herein we disclose our studies on the development of a 


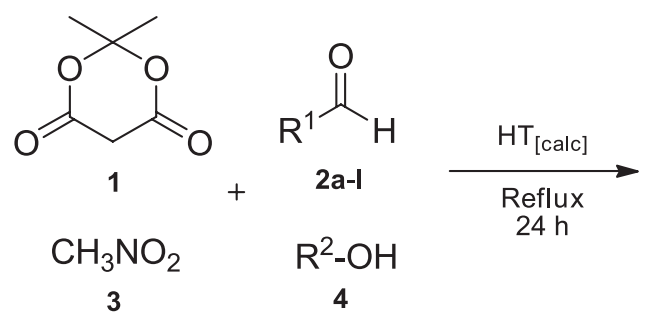<smiles>[R]OC(=O)CC([R])C[N+](=O)[O-]</smiles>

Scheme 1. Multicomponent synthesis of $\gamma$-nitroesters 5a-u.

new multicomponent/domino combined approach for the direct synthesis of $\gamma$-nitroesters (5) from the reaction of Meldrum's acid (1), aromatic aldehydes 2, nitromethane (3) and an alcohol $\mathbf{4}$ as the solvent, promoted by calcined hydrotalcite-like compounds.

Our interest synthesizing $\gamma$-nitroesters is due to the fact that these intermediates are considered advanced intermediates in the synthesis of GABA analogues. ${ }^{25-27}$ Thus, the development of multicomponent methodologies permitting the rapid access to this class of compounds is of great interest. To our best knowledge, this tetracomponent synthesis of $\gamma$-nitroesters was not reported in the literature.

To gain insights about the mechanistic details of this new multicomponent process, we have used the mass spectrometric techniques which are recognized as a powerful method to reveal details of several reaction processes. ${ }^{28-33}$

Electrospray ionization mass spectrometry (ESI-MS) has become the central technique, as it often allows real-time detection and ESI-tandem mass spectrometric (MS/MS) characterization of reactants, intermediates and final products. Major reaction processes have been investigated via ESI-MS techniques, and even transient reaction intermediates and catalyst complexes have been intercepted and characterized. ${ }^{34-38}$ The present work also aims to apply on-line ESI-MS/MS to monitor the developed multicomponent reactions.

\section{Results and Discussion}

The multicomponent/domino combined approach

Previous studies from our laboratory demonstrated the ability of HT to promote the direct Michael addition of 1,3-dicarbonyl compounds to nitrostyrenes, resulting in the formation of $\beta$-aryl- $\gamma$-nitrocarbonyl compounds. We also observed that HT combined with Meldrum's acid resulted in the formation of $\gamma$-nitroesters directly. ${ }^{25}$

The activity of HT was attributed to the increase in the basicity of this material by the formation of mixed magnesium and aluminium oxides after thermal treatment that we called $\mathrm{HT}_{[\text {Calc.] }}{ }^{26}$
Encouraged by the fact that HT is able to promote the Henry reactions, ${ }^{27}$ we hypothesized that $\mathrm{HT}_{\text {[Calc.] }}$ could promote the in situ preparation of nitrostyrenes through a Knoevenagel-type reaction from aldehydes and nitromethane. Once the nitrostyrene is present in the reaction media, the 1,4-addition of Meldrum's acid takes place, performing a one-pot multicomponent synthesis of $\gamma$-nitroesters.

According to this assumption, our approach was based on a new MCR/domino combined reaction of Meldrum's acid (1), aromatic aldehydes $\mathbf{2}$, nitromethane (3) and an alcohol $\mathbf{4}$ as the solvent. In this process, the calcined hydrotalcite $\left(\mathrm{HT}_{[\text {Calc.] }}\right)$, used as catalyst, proved to be essential to afford the $\gamma$-nitroesters 5 (Scheme 1).

To our satisfaction, the reactions carried out in $\mathrm{EtOH}$ afforded the $\boldsymbol{\gamma}$-nitroesters $\mathbf{5} \mathbf{a}$-j in reasonable to good yields. The results are shown in Table 1.

Table 1. Multicomponent synthesis of $\beta$-aryl- $\gamma$-nitroesters 5a-1

\begin{tabular}{lcccc}
\hline entry & $\mathrm{R}^{1}$ & $\mathrm{R}^{2}$ & Nitroester & Yield / \% \\
\hline 1 & $\mathrm{C}_{6} \mathrm{H}_{5}$ & $\mathrm{EtOH}$ & $\mathbf{5 a}$ & 88 \\
2 & $4-\mathrm{Cl}-\mathrm{C}_{6} \mathrm{H}_{4}$ & $\mathrm{EtOH}$ & $\mathbf{5 b}$ & 83 \\
3 & $4-\mathrm{Br}-\mathrm{C}_{6} \mathrm{H}_{4}$ & $\mathrm{EtOH}$ & $\mathbf{5 c}$ & 88 \\
4 & $4-\mathrm{F}-\mathrm{C}_{6} \mathrm{H}_{4}$ & $\mathrm{EtOH}$ & $\mathbf{5 d}$ & 90 \\
5 & $4-\mathrm{CN}-\mathrm{C}_{6} \mathrm{H}_{4}$ & $\mathrm{EtOH}$ & $\mathbf{5 e}$ & 80 \\
6 & $4-\mathrm{MeO}-\mathrm{C}_{6} \mathrm{H}_{4}$ & $\mathrm{EtOH}$ & $\mathbf{5 f}$ & 70 \\
7 & $3,4-(\mathrm{MeO})_{2}-\mathrm{C}_{6} \mathrm{H}_{3}$ & $\mathrm{EtOH}$ & $\mathbf{5 g}$ & 75 \\
8 & $3,4,5-(\mathrm{MeO})_{3}-\mathrm{C}_{6} \mathrm{H}_{2}$ & $\mathrm{EtOH}$ & $\mathbf{5 h}$ & 95 \\
9 & $2-\mathrm{thienyl}$ & $\mathrm{EtOH}$ & $\mathbf{5 i}$ & 85 \\
10 & $3-$ thienyl & $\mathrm{EtOH}$ & $\mathbf{5 j}$ & 83 \\
11 & $n \mathrm{Bu}_{12}$ & $\mathrm{EtOH}$ & $\mathbf{5 k}$ & 15 \\
12 & $i P r$ & $\mathrm{EtOH}$ & $\mathbf{5 l}$ & 17 \\
13 & $\mathrm{C}_{6} \mathrm{H}_{5}$ & $\mathrm{EtOH}$ & $\mathbf{5 a}$ & $88^{\mathrm{a}}$ \\
14 & $\mathrm{C}_{6} \mathrm{H}_{5}$ & $\mathrm{EtOH}$ & $\mathbf{5 a}$ & $85^{\mathrm{b}}$ \\
15 & $\mathrm{C}_{6} \mathrm{H}_{5}$ & $\mathrm{EtOH}$ & $\mathbf{5 a}$ & $70^{\mathrm{c}}$ \\
\hline
\end{tabular}

${ }^{\mathrm{a}} 1^{\text {st }}$ recycle; ${ }^{\mathrm{b}} \mathrm{2}^{\text {nd }}$ recycle; ${ }^{\mathrm{c}} 3^{\text {rd }}$ recycle.

The results show the multicomponent process occurred in a single step promoted by $\mathrm{HT}_{\text {[Calc.] }}$ and was effective for both electron-withdrawing or electron-donating groups attached to the aromatic ring (Table 1, entries 2-5 and 
entries 6-8, respectively). Nitroesters with heteroaromatic substituents were also synthesized in good yields (entries 9 and 10, respectively). However, the employment of aliphatic aldehydes afforded the $\gamma$-nitroesters in very poor yields. This fact was interpreted as being a consequence of the auto-condensation of aldehydes under basic media (entries 11 and 12, respectively). Experiments investigating the recycling of the $\mathrm{HT}_{\text {[Calc.] }}$ catalyst were performed by the isolation and re-calcination of $\mathrm{HT}_{\text {[Calc.] }}$. The $1^{\text {st }}$ reuse resulted in a slightly diminished yield. The $2^{\text {nd }}$ and $3^{\text {rd }}$ reuses confirmed the gradual decrease in the activity (entries 13, 14 and 15 , respectively).

The behavior of the multicomponent reaction in the presence of ethyl malonate instead of Meldrun's acid was also investigated. In this case, the main product was identified as a $\gamma$-nitro-dicarbonylic compound formed in only a $30 \%$ yield. This result indicates the combination of Meldrum's acid and HT is essential to the preparation of $\gamma$-nitroesters in one step. As only ethyl esters were produced, we speculate that this was due to the use of ethanol as the solvent in the multicomponent process. To prove this assumption, a set of reactions were carried out in the presence of different alcohols, with the goal of producing different alkyl esters. The MCRs were performed in methanol (4b), isopropanol (4c), $n$-butanol (4d), tert-butanol (4e), benzyl alcohol (4f), allyl alcohol (4g) and propargyl alcohol (4h)
Table 2. Synthesis of $\mathbf{5 m - u}$ in the presence of different alcohols

\begin{tabular}{lcccc}
\hline entry & $\mathrm{R}^{1}$ & $\mathrm{R}^{2}$ & Nitroesters & Yield /\% \\
\hline 1 & $\mathrm{C}_{6} \mathrm{H}_{5}$ & $\mathrm{MeOH}$ & $\mathbf{5 m}$ & 84 \\
2 & $4-\mathrm{MeO}-\mathrm{C}_{6} \mathrm{H}_{4}$ & $\mathrm{MeOH}$ & $\mathbf{5 n}$ & 72 \\
3 & $\mathrm{C}_{6} \mathrm{H}_{5}$ & $i \mathrm{PrOH}$ & $\mathbf{5 o}$ & 75 \\
4 & $4-\mathrm{MeO}-\mathrm{C}_{6} \mathrm{H}_{4}$ & $i \mathrm{PrOH}$ & $\mathbf{5 p}$ & 64 \\
5 & $4-\mathrm{MeO}-\mathrm{C}_{6} \mathrm{H}_{4}$ & $n \mathrm{BuOH}$ & $\mathbf{5 q}$ & 55 \\
6 & $\mathrm{C}_{6} \mathrm{H}_{5}$ & ${ }^{t} \mathrm{BuOH}$ & $\mathbf{5 r}$ & 58 \\
7 & $\mathrm{C}_{6} \mathrm{H}_{5}$ & $\mathrm{BnOH}$ & $\mathbf{5 s}$ & $60^{\mathrm{b}}$ \\
8 & $\mathrm{C}_{6} \mathrm{H}_{5}$ & allyl & $\mathbf{5 t}$ & $75^{\text {b }}$ \\
9 & $\mathrm{C}_{6} \mathrm{H}_{5}$ & propargyl & $\mathbf{5 u}$ & $65^{\mathrm{b}}$ \\
\hline
\end{tabular}

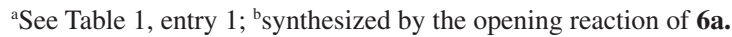

as shown in the Scheme 1. The results are shown in Table 2.

In all cases, the $\gamma$-nitroesters $\mathbf{5 m}$-u were formed in reasonable to good yields. These reactions proved the direct participation of the alcoholic solvent, which also acted as a reagent. The influence of each type of alcohol is not totally clear. For example, low yields of $\gamma$-nitroesters were observed in $n-\mathrm{BuOH}$ or tert-BuOH (Table 2 , entries 5 and 6 , respectively). The chemical structures of $\gamma$-nitroesters $\mathbf{5 a - u}$ prepared from different aromatic aldehydes are depicted in the Figure 1.<smiles>CCOC(=O)CC(C[N+](=O)[O-])c1ccccc1</smiles>

5a - $88 \%$<smiles>CCOC(=O)CC(C[N+](=O)[O-])c1ccc(Cl)cc1</smiles>

$\mathbf{5 b}-83 \%$<smiles>CCOC(=O)CC(C[N+](=O)[O-])c1ccc(Br)cc1</smiles>

5c - $88 \%$<smiles>CCOC(=O)CC(C[N+](=O)[O-])c1ccc(F)cc1</smiles>

5d- $90 \%$<smiles>CCOC(=O)CC(C[N+](=O)[O-])c1ccc(C#N)cc1</smiles>

5e - $80 \%$<smiles>CCOC(=O)CC(C[N+](=O)[O-])c1ccc(OC)cc1</smiles><smiles></smiles><smiles>CCOC(=O)CC(C[N+](=O)[O-])c1cc(OC)c(OC)c(OC)c1</smiles><smiles>CCOC(=O)CC(CNC(=O)[O-])c1cccs1</smiles><smiles>CCOC(=O)CC(C[N+](=O)[O-])c1ccsc1</smiles><smiles>CCCCCC(CC(=O)OCC)C[N+](=O)[O-]</smiles>

5k- $15 \%$<smiles>CCOC(=O)CC(C[N+](=O)[O-])C(C)C</smiles>

5I - $21 \%$<smiles>COC(=O)CC(C[N+](=O)[O-])c1ccccc1</smiles>

5m - $84 \%$<smiles>COC(=O)CC(C[N+](=O)[O-])c1ccc(OC)cc1</smiles>

5n - $72 \%$<smiles>CCCOC(=O)CC(C[N+](=O)[O-])c1ccccc1</smiles>

5o- $75 \%$<smiles>CCCC(=O)OCC(CN=[N+]([O-])[O-])c1ccc(OC)cc1</smiles><smiles>CCCCC(CC(CC(=O)OCC)c1ccc(OC)cc1)[N+](=O)[O-]</smiles><smiles>CCCCOC(=O)CC(CN[13C](=O)[O-])c1ccccc1</smiles><smiles>O=C(CC(=O)OCc1ccccc1)CC(C[N+](=O)[O-])c1ccccc1</smiles><smiles>C=CCOC(=O)CC(C[N+](=O)[O-])c1ccc(OC)cc1</smiles><smiles></smiles>

Figure 1. Structurally diverse $\gamma$-nitroesters prepared via the new tetracomponent reaction. 
<smiles>CC1(C)OC(=O)CC(=O)[OH+]1</smiles>

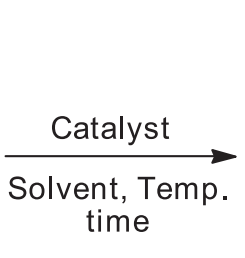<smiles>CC1(C)OC(=O)C(C(c2ccccc2)c2ccccc2)C(=O)O1</smiles>

Scheme 2. Synthesis of Michael adduct $6 \mathbf{a}$.

Speculating about the reaction mechanism, we presumed that the alcoholic solvent is able to promote the opening and transesterification of the Meldrum's acid moiety in the Michael adduct initially formed. ${ }^{25}$ The adduct $6 \mathbf{a}$ was not isolated during the multicomponent process. Thus, we focused our efforts on its isolation and characterization. Assuming the nitrostyrene $\mathbf{7 a}$ is being formed during the course of the multicomponent process, we performed two sets of specific reactions using Meldrum's acid and nitrostyrene (Scheme 2).

The first set was performed in presence of $\mathrm{HT}_{\text {[Calc. }]}$ in nonalcoholic solvents because $\gamma$-nitroesters $5 \mathbf{a}$ were produced in the presence of EtOH. In the second set, an amine basecatalyzed conjugated addition was used in ethanol as the solvent. Under both of these new conditions, we were able to isolate the intermediate $\mathbf{6 a}$ in good yields. Unfortunately, attempts to purify $\mathbf{6 a}$ by column chromatography were unsuccessful due to the degradation of the product on silica.

Thus, the yields of these reactions were inferred by ${ }^{1} \mathrm{H}$ nuclear magnetic resonance (NMR) spectra from the crude mixture after carefully removing the $\mathrm{HT}_{\text {[Calc.] }}$ from the crude mixture of organics. The results are shown in the Table 3.

As seen in Table 3, the $\mathrm{HT}_{\text {[Calc.] }}$ was able to promote the Michael addition of Meldrum's acid to the nitrostyrene in different non-protic solvents such as $\mathrm{CH}_{2} \mathrm{Cl}_{2}, \mathrm{CH}_{3} \mathrm{CN}$, and tetrahydrofuran (THF) to afford compound $\mathbf{6 a}$ in good yields (entries 1, 2, and 3, respectively). The use of tertiary amines as basic catalysts also furnished $\mathbf{6}$ in both non-protic (entry 4) and protic solvents (entries 5-10). It is important to note that even with EtOH under reflux conditions (entries 7 and 9, respectively) no degradation of $\mathbf{6 a}$ was observed, revealing that the transformation from $\mathbf{6 a}$ to $\mathbf{5 a}$ does not occur through the use of basic media containing simple amines. To ensure that the transformation could be made independently, 6a was
Table 3. Preparation of intermediate $\mathbf{6 a}$

\begin{tabular}{lccccc}
\hline entry & Catalyst & Solvent & time $/ \mathrm{h}$ & Temperature $/{ }^{\circ} \mathrm{C}$ & Yield $^{\mathrm{a}} \%$ \\
\hline 1 & $\mathrm{HT}_{[\text {Calc.] }}$ & $\mathrm{CH}_{2} \mathrm{Cl}_{2}$ & 24 & 25 & 80 \\
2 & $\mathrm{HT}_{\text {[Calc.] }}$ & $\mathrm{CH}_{3} \mathrm{CN}$ & 24 & 25 & 61 \\
3 & $\mathrm{HT}_{[\text {Calc.] }}$ & $\mathrm{THF}$ & 24 & 60 & 95 \\
4 & DIPEA & $\mathrm{CH}_{3} \mathrm{CN}$ & 8 & 25 & 45 \\
5 & DIPEA & $\mathrm{EtOH}$ & 8 & 25 & 67 \\
6 & DIPEA & EtOH & 24 & 25 & 95 \\
7 & DIPEA & EtOH & 8 & reflux & 95 \\
8 & DABCO & EtOH & 5 & 60 & 95 \\
9 & DABCO & EtOH & 3 & reflux & 95 \\
10 & DBU & EtOH & 24 & 25 & 50 \\
11 & Et ${ }_{3} \mathrm{~N}$ & EtOH & 24 & 25 & 95 \\
\hline
\end{tabular}

${ }^{a}$ Yields estimated by ${ }^{1} \mathrm{H}$ NMR analysis; THF: tetrahydrofuran; DIPEA: $N, N$-diisopropylethylamine; DABCO: 1,4-diazabicyclo[2.2.2] octane; DBU: 1,8-diazabicyclo[5.4.0]undec-7-ene.

reacted with $\mathrm{EtOH}$ in the presence of $\mathrm{HT}_{[\text {Calc.] }}$ for $24 \mathrm{~h}$ under reflux conditions. After this time, the $\mathrm{HT}_{[\text {[Calc.] }}$ was filtered off, and the volatiles were removed under vacuum. The crude product was purified by column chromatography to afford the 5a in a $90 \%$ yield, confirming the pivotal action of $\mathrm{HT}_{\text {[Calc.] }}$ in this step (Scheme 3 ).

We believe that the presence of metal centers of $\mathrm{HT}_{\text {[Calc.] }}$ could be act as weak Lewis acid sites coordinating with the oxygen base Lewis site of Meldrum's acid moiety, aiding the starting the process to transformation of $\mathbf{6 a}$ into $\mathbf{5 a}$. Thus, this could evidence a dual acid/base properties of the $\mathrm{HT}_{\text {[Calc.] }}$ This idea was supported by the ESI-MS studies and will be discussed later.

\section{A tentative mechanistic pathway by GC-MS studies}

Once the formation of nitrostyrene 7a was suggested during the course of the reaction, we decided to investigate<smiles>CC1(C)OC(=O)C(C(c2ccccc2)c2ccccc2)C(=O)O1</smiles>

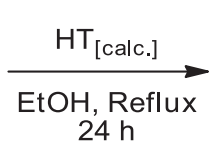

6 a<smiles></smiles>

Scheme 3. Transformation of intermediate 6 into $\gamma$-nitroester $5 \mathbf{a}$. 
the ability of HT in the formation of 7a by Henry reaction, followed by a direct dehydration step. The reaction was performed from aldehyde $\mathbf{2 a}$ and nitromethane (3), in the presence of $\mathrm{HT}_{\text {[Calc.] }}$ and $\mathrm{EtOH}$ under reflux as shown in Scheme 4.

The reaction was carefully monitored through the gas chromatography-mass spectrometry (GC-MS) analysis. After $30 \mathrm{~min}$, the chromatogram showed signals corresponding to benzaldehyde ( $\mathrm{Rt}=4.29 \mathrm{~min}$, $\mathrm{m} / \mathrm{z}$ 106), nitrostyrene (7a) $(\mathrm{Rt}=10.49 \mathrm{~min}, \mathrm{~m} / \mathrm{z}$ 149), and nitroaldol 8a $(\mathrm{Rt}=11.02 \mathrm{~min}, \mathrm{~m} / \mathrm{z}$ 167) (Figure 2a). Analysis of aliquots after 1.0 and $1.5 \mathrm{~h}$ of reaction time showed a gradual increase in the formation of $\mathbf{7 a}$, confirming its formation under the conditions of the MCR protocol.

The nitroester 5a was the main product. Because the GC-MS analysis was useful in monitoring this step, we decided to extend the method to follow the course of the MCR process to identify other possible intermediates. A new experiment was started, and the first analysis was made $10 \mathrm{~min}$ after all of the components had been mixed. At this time, the chromatogram did not reveal the presence of 7a. Instead, a signal at Rt $=16.08 \mathrm{~min}$ $(\mathrm{m} / \mathrm{z}, 232)$ was observed. This signal was characterized as being the benzylidene adduct 9a, most likely formed from the Knoevenagel-type condensation of Meldrum's acid (1) and benzaldehyde (Figure 2B). After $1.0 \mathrm{~h}$, the nitrostyrene (7a) at $\mathrm{Rt}=10.50 \mathrm{~min}(\mathrm{~m} / \mathrm{z}, 149)$ and nitroaldol $\mathbf{8} \mathbf{a}$ at $\mathrm{Rt}=11.20 \mathrm{~min}(\mathrm{~m} / \mathrm{z} 167)$ were detected. The desired nitroester 5a was also identified at $\mathrm{Rt}=14.65 \mathrm{~min}(\mathrm{~m} / \mathrm{z} 237)$ as well as the benzylidene adduct $9 \mathbf{a}$ at $\mathrm{Rt}=16.14 \mathrm{~min}$ $(\mathrm{m} / \mathrm{z}, 232)$ (Figure 2C). Other aliquots were analyzed after 3.0, 5.0, 8.0, and $11.0 \mathrm{~h}$, respectively. From these chromatograms, we observed gradual decreases in the signals of 7a and 9a and an increase in the signal of $\gamma$-nitroester $\mathbf{5 a}$.

After $24 \mathrm{~h}$, the GC-MS analysis revealed that the $\gamma$-nitroester 5a was the principal component as well as the almost complete consumption of all of the reagents (Figure 2D).

As we postulated, the formation of adduct $\mathbf{6 a}$ occurred via the Michael addiction of Meldrum's acid to nitrostyrene, and we decided to confirm that the benzylidene derivative was also involved in the formation of $\gamma$-nitroesters. Thus, 9a was prepared independently by the condensation of Meldrum's acid and benzaldehyde in presence of $\mathrm{HT}_{\text {[Calc.] }}$ under refluxing EtOH. The benzylidene adduct was isolated in a $98 \%$ yield.

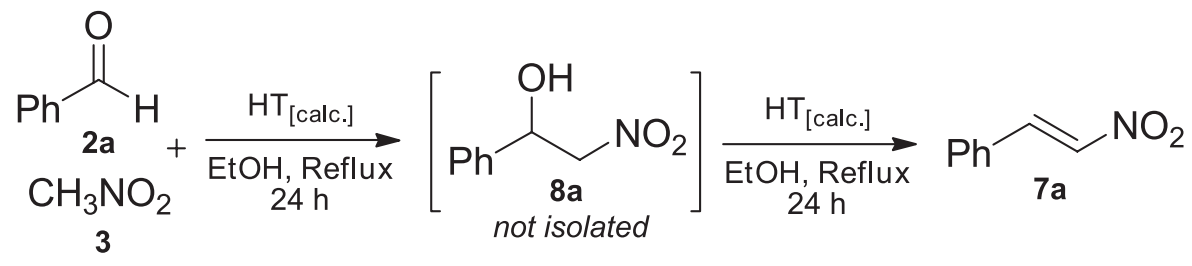

Scheme 4. Formation of 7a via a Knoevenagel-type reaction.
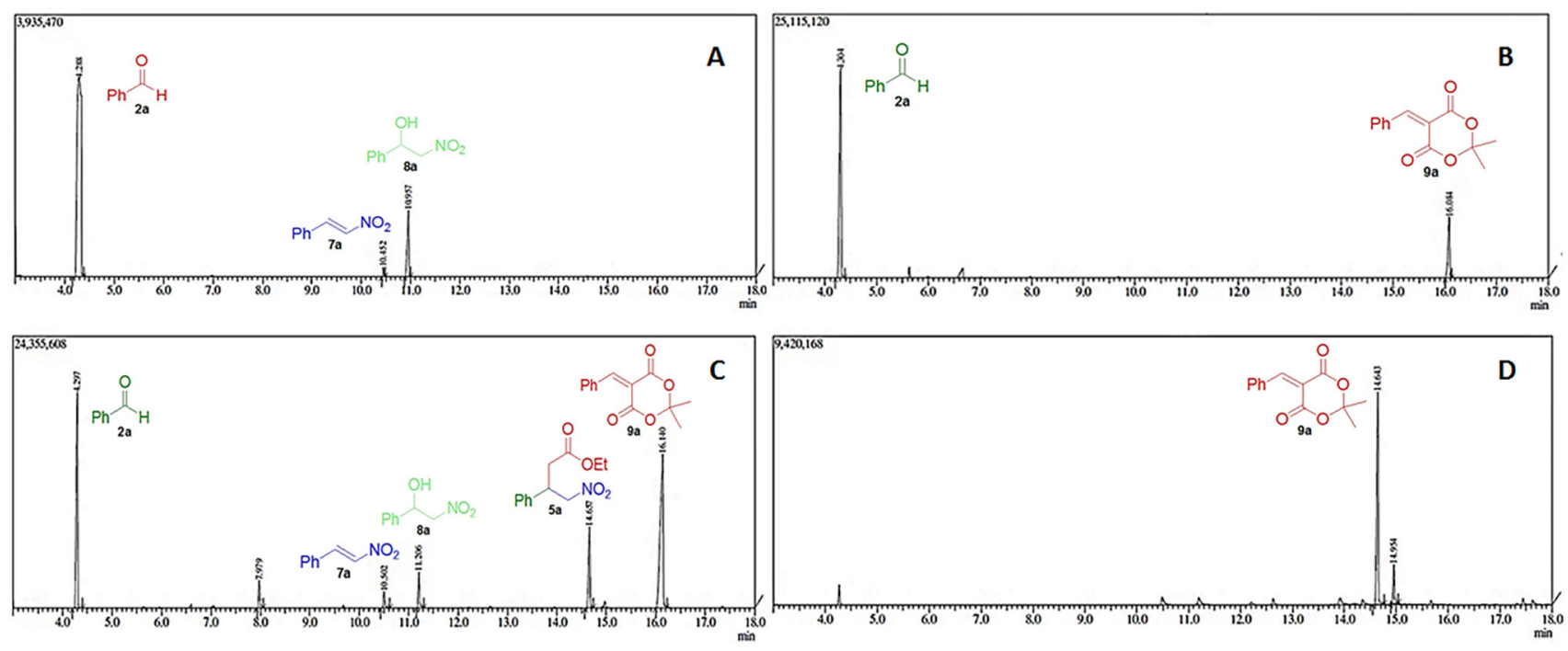

Figure 2. (A) GC-MS after 30 min of Henry reaction in the presence of $\mathrm{HT}_{[\text {Calc.] }}$. Detection of intermediates 7a and 8a; (B) GC-MS after 10 min of the MCR process. Detection of the benzylidene adduct 9a; (C) GC-MS after 1.0 hour of the MCR process. Detection of intermediates 7a, $\mathbf{8 a}$ and $9 \mathbf{a}$ as well as the final product the nitroester 5a; (D) GC-MS after 24 hours of the MCR process. 
Next, nitromethane was added to benzylidene in the presence of $\mathrm{HT}_{[\text {Calc.] }}$ in EtOH as the solvent. After 6 hours of reflux, we obtained the respective $\gamma$-nitroester $\mathbf{5 a}$ in a $95 \%$ yield after purification by column chromatography (Scheme 5).

Based on these results, we postulated a combined multicomponent/domino reaction sequence to explain the formation of $\gamma$-nitroesters $\mathbf{5 a - u}$. However, it seems that two different competitive MCRs can explain the formation of the common intermediate $\mathbf{6 a}$. One of them occurs via Knoevenagel-type condensation of Meldrum's acid and benzaldehyde to afford the benzylidene intermediate 9a. The second one also starts with a Knoevenagel-type condensation of nitromethane and benzaldehyde to form the nitrostyrene 7a. The conversion of common intermediate $\mathbf{6 a}$ in the $\gamma$-nitroester occurs through a one pot domino process, with the loss of acetone and $\mathrm{CO}_{2}$ along with including an esterification step (Scheme 6).

Investigation of the mechanistic pathway by ESI-MS/MS studies

In this study, we describe the results of the mechanistic investigation of the MCR synthesis of $\gamma$-nitroesters by ESIMS/MS. To accomplish this task, model experiments were performed using Meldrum's acid (1, $1 \mathrm{mmol})$, benzaldehyde (2a, $1 \mathrm{mmol})$ and nitromethane $(\mathbf{3}, 5 \mathrm{mmol})$ in conditions showed in Table 1, for the synthesis of nitroesters. The monitoring of the reaction was realized by the removal of aliquots $(100 \mu \mathrm{L})$ every 5 minutes.

The aliquots were diluted in $1.5 \mathrm{~mL}$ of the solvent used in the reaction medium $(\mathrm{MeOH})$ and filtered for direct injection into the ion source of the mass spectrometer using

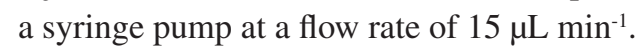

The monitoring by ESI-MS/MS showed one major pathway in the multicomponent process. In the first event, the Knoevenagel condensation of benzaldehyde and Meldrum's acid leads to formation of benzylidene intermediate $\mathbf{9 a}$ of $\mathrm{m} / \mathrm{z} 255\left([\mathrm{M}+\mathrm{Na}]^{+}\right)$(Figure 3A). After 30 minutes of reaction, the benzylidene acts as a Michael acceptor for the addition of nitromethane (3), affording the Michael adduct $\mathbf{6 a}$ of $\mathrm{m} / \mathrm{z} 316\left([\mathrm{M}+\mathrm{Na}]^{+}\right)$(Figure 3B). The spectrum obtained after 60 minutes in the presence of $\mathrm{HT}_{\text {[Calc.] }}(50 \mathrm{mg})$ and $\mathrm{MeOH}(3 \mathrm{~mL})$ under reflux already shows the presence of the nitroester $\mathbf{5 a}$ of $\mathrm{m} / 2246\left([\mathrm{M}+\mathrm{Na}]^{+}\right)$formed from a domino transformation process of $\mathbf{6} \mathbf{a}$ into nitroester $\mathbf{5 a}$ (Figure 3C).

To prove the statement above, the Michael adduct $\mathbf{6 a}$ was submitted to an opening reaction. At $\mathrm{t}_{1}=5 \mathrm{~min}$, it was possible to identify the presence of two species of $m / z 214$ $\left([\mathrm{M}+\mathrm{Na}]^{+}\right)$and $m / z 258\left([\mathrm{M}+\mathrm{Na}]^{+}\right)$, corresponding to ketene derivatives $\mathbf{1 0}$ and $\mathbf{1 1}$, respectively, both as sodiated species (Figure 4A). ${ }^{39}$<smiles>CC1(C)OC(=O)CC(=O)O1</smiles><smiles>CC1(C)OC(=O)C(=Cc2ccccc2)C(=O)O1</smiles>

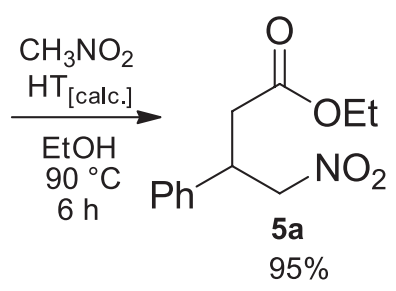

Scheme 5. Preparation of $\mathbf{5 a}$ from benzylidene intermediate $\mathbf{9 a}$.

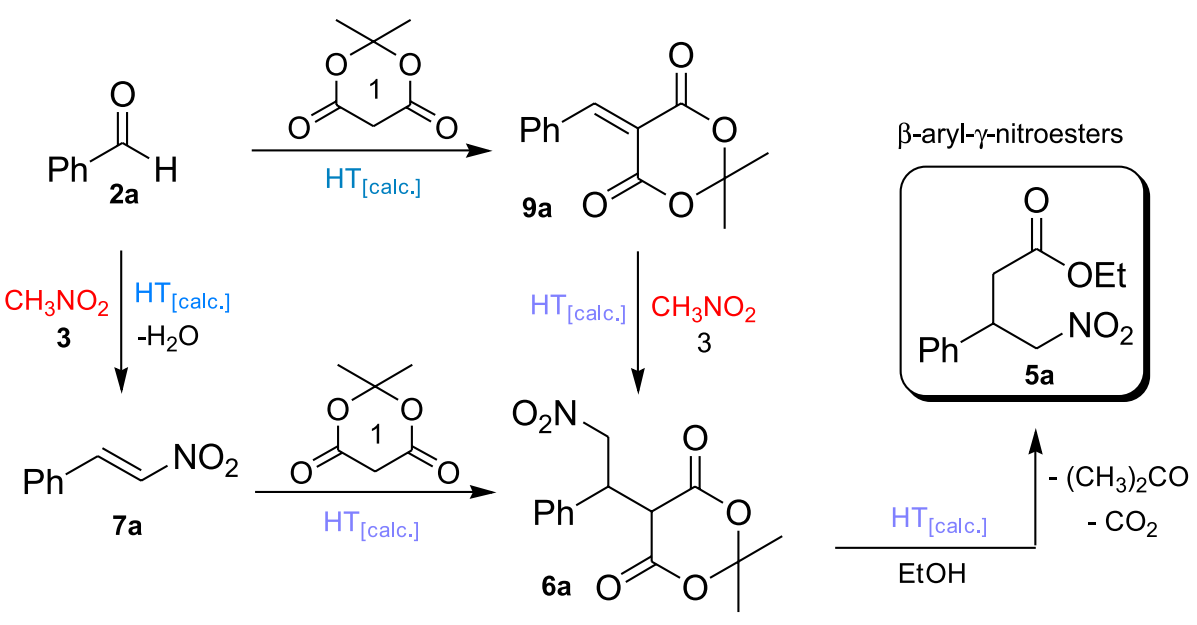

Scheme 6. A rational mechanism for the multicomponent synthesis of $\gamma$-nitroesters. 
After 20 minutes, the presence of a new species of $\mathrm{m} / z, 290\left([\mathrm{M}+\mathrm{Na}]^{+}\right)$was observed, which was identified as the malonic acid methyl half-ester intermediate $\mathbf{1 2}$ (Figure 4B). After 1 hour, the main product observed was 5a of $m / z 246\left([\mathrm{M}+\mathrm{Na}]^{+}\right)$, formed through a decarboxylation reaction (Figure 4C).

According to the experiments carried out, we rationalized that the reaction occurs initially by Knoevenagel condensation to form $\mathbf{9 a}$, followed by Michael addiction of Meldrum's acid to produce the adduct $\mathbf{6 a}$. These steps were related to the multicomponent process. The opening of Meldrum's acid moiety of $\mathbf{6 a}$ can occur by a possible two pathways to form directly the half-ester $\mathbf{1 2}$ or via ketene intermediates wards the opening of Meldrum's moiety occur via ketene intermediate 11. Both intermediates $\mathbf{1 1}$ and $\mathbf{1 2}$ can be transformed into the $\gamma$-nitroesters $5 \mathbf{a}$ through further simple loss of $\mathrm{CO}_{2}$ and/or $\mathrm{MeOH}$ addition. The opening process of Meldrum's acid moiety of $\mathbf{6} \mathbf{a}$ and their subsequent transformation into de $\gamma$-nitroester 5a were related to a domino process (Scheme 7).

The synthesis GABA derivatives (+/-)-Phenibut, (+/-)-Baclofen

Phenibut (4-amino-3-phenylbutanoic acid, 16) and
Baclofen (4-amino-3-(4-chlorophenyl)butanoic acid, 17) are both lipophilic analogues of $\gamma$-aminobutyric acid (GABA), and they exhibit different pharmacological properties. Phenibut is mainly used as a tranquilizer or increasingly as a mood modulator. ${ }^{40}$ Baclofen, meanwhile, is a muscle relaxant currently used in the treatment of neuropathic pain. ${ }^{41}$ The $(-)-(R)$-enantiomer is identified as being responsible for the biological activity; however, Baclofen is commercialized in its racemic form.

To demonstrate the potential application of the $\gamma$-nitroesters in the synthesis of the GABA-derivatives, the Phenibut (16) and Baclofen (17) were prepared in two steps from the $\gamma$-nitroesters $\mathbf{5 a}$ and $\mathbf{5 b}$, respectively. The reduction of the nitro group in the presence of $\mathrm{NaBH}_{4} / \mathrm{NiCl}_{2} \cdot 6 \mathrm{H}_{2} \mathrm{O}$ in ethanol led directly to the isolation of the lactams $\mathbf{1 4}$ and $\mathbf{1 5}$ in yields of 82 and $87 \%$, respectively. ${ }^{42}$

The transformation of the respective lactams into the GABA-derivatives was achieved in presence of $\mathrm{HCl} 6 \mathrm{~mol} \mathrm{~L}^{-1}$, under reflux for 12 hours. ${ }^{43}$ Afterwards, Phenibut was isolated in an $88 \%$ yield, and Baclofen was produced in an $89 \%$ yield, both in the chloridrate form. Thus, Phenibut and Bacofen were expeditiously synthesized from Meldrum's acid in only 3 steps in overall yields of 63 and $61 \%$, respectively (Scheme 8).
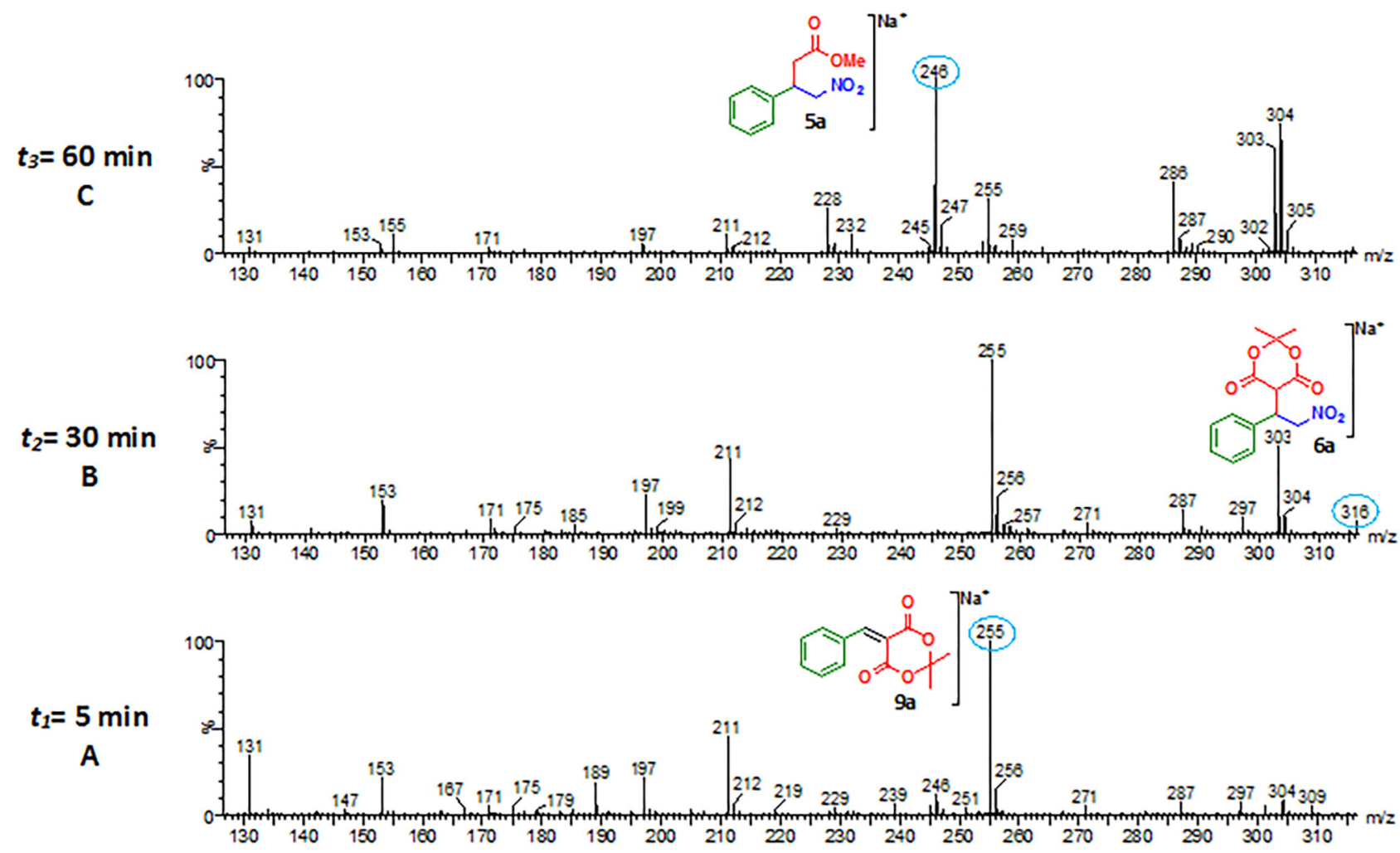

Figure 3. ESI-MS spectra from a solution of benzaldehyde/Meldrum's acid/nitromethane/HT at different reaction times of $(A) t_{1}=5 \mathrm{~min}$; (B) $t_{2}=30 \mathrm{~min}$; (C) $\mathrm{t}_{3}=60 \mathrm{~min}$. 

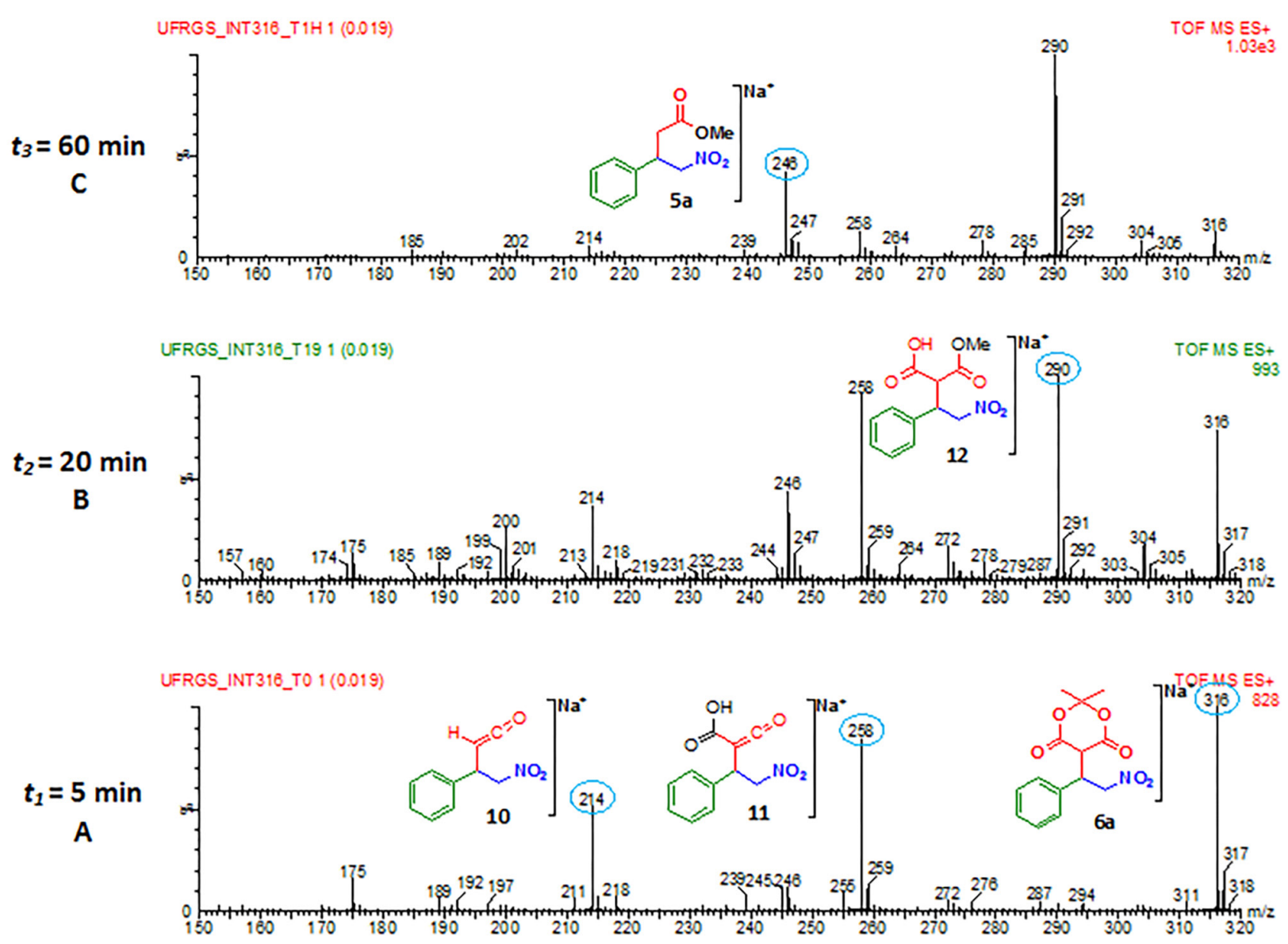

Figure 4. ESI-MS spectra from the solution of a one pot domino transformation of $\mathbf{6 a}$ into $\gamma$-nitroester $\mathbf{5 a}$ at different times of (A) $t_{1}=5$ min; (B) $\mathrm{t}_{2}=20 \mathrm{~min} ;(\mathrm{C}) \mathrm{t}_{3}=60 \mathrm{~min}$.

\section{Conclusions}

In the present work, a new multicomponent reaction between Meldrum's acid, aromatic aldehydes, nitromethane and alcoholic solvents was developed to afford the direct synthesis of $\beta$-aryl- $\gamma$-nitroesters 5a-u with yields ranging between 15 and $95 \%$. It was demonstrated that the hydrotalcite-derived metal oxides as heterogeneous catalyst, plays a role promoting the one pot single-step process. The use of GC and ESI-MS analysis for monitoring the course of the reactions revealed the convergent mechanistic pathways towards the formation of a common intermediate $\mathbf{6}$ in a multicomponent process, while its transformation into the $\gamma$-nitroesters occurs through a domino process. Thus, the $\gamma$-nitroesters $\mathbf{5 a}$ and $\mathbf{5 b}$ produce by this way were easily converted into the lipophilic GABA derivatives Phenibut (16) and Baclofen (17) in 3 steps in 63 and 61\% overall yields, respectively.

\section{Experimental}

All solvents for the routine isolation of products and chromatography were of reagent grade. Flash chromatography was performed using silica gel (230-400 mesh). All reactions were monitored by thin-layer chromatography on $0.25 \mathrm{~mm}$ silica plates $(60 \mathrm{~F}-$ 254) and visualized with UV light or iodine. ${ }^{1} \mathrm{H}$ NMR and ${ }^{13} \mathrm{C}$ NMR spectra were recorded either on a 300,75 or $400,100 \mathrm{MHz}$ spectrometers, respectively. Chemical shifts $(\delta)$ are reported in ppm relative to tetramethylsilane (TMS). The multiplicity of signals is expressed as: $s$ (singlet); d (doublet); dd (double doublet); t (triplet); q (quartet) and $\mathrm{m}$ (multiplet), and the coupling constant ${ }^{3} J$ is expressed in hertz $(\mathrm{Hz})$. Infrared (IR) spectra were recorded on a Varian 640-IR spectrometer and are expressed in $\mathrm{cm}^{-1}$ in the range of $4000-400 \mathrm{~cm}^{-1}$. Melting points were measured on Olympus BX41 microscope equipped with a Mettler-Toledo FP82HT hotplate. ESI-MS and ESI-MS/MS experiments in the positive ion-mode were performed on a high-resolution hybrid quadrupole $(\mathrm{Q})$ and orthogonal timeof-flight (TOF) mass spectrometer (Q-TOF Micro, WatersMicromass, UK) with a constant nebulizer temperature of $100{ }^{\circ} \mathrm{C}$ and a capillary voltage of $3.0 \mathrm{~V}$. The cone and extractor potentials were set to 15 and $4.5 \mathrm{~V}$, respectively, 


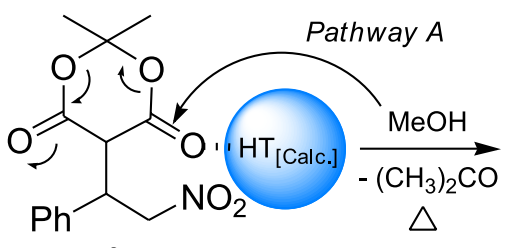

$6 a$

Exact Mass 293.09

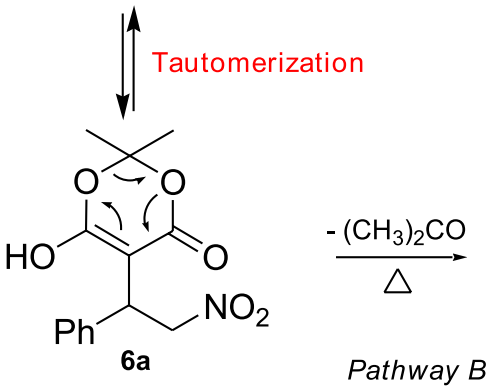

Exact Mass 293.09<smiles>COC(=O)C(C(=O)OC)C(C[N+](=O)[O-])c1ccccc1</smiles>

12

Exact Mass 267.07<smiles>CCCC(=O)C(C(=O)O)C(C[N+](=O)[O-])c1ccccc1</smiles>

Exact Mass 235.05<smiles>CC(C)C(=O)O</smiles><smiles>O=C=CC(C[N+](=O)[O-])c1ccccc1</smiles>

10

Exact Mass 191.06
13

Exact Mass 223.08

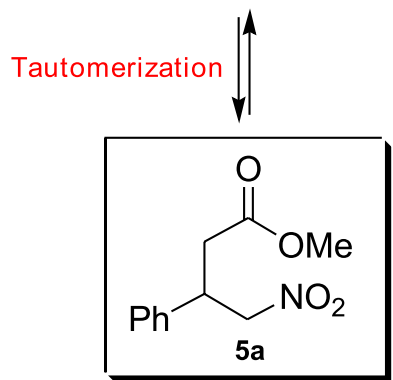

Exact Mass 223.06<smiles>CC(O)[In]</smiles>

Scheme 7. A tentative mechanism based on ESI-MS studies.

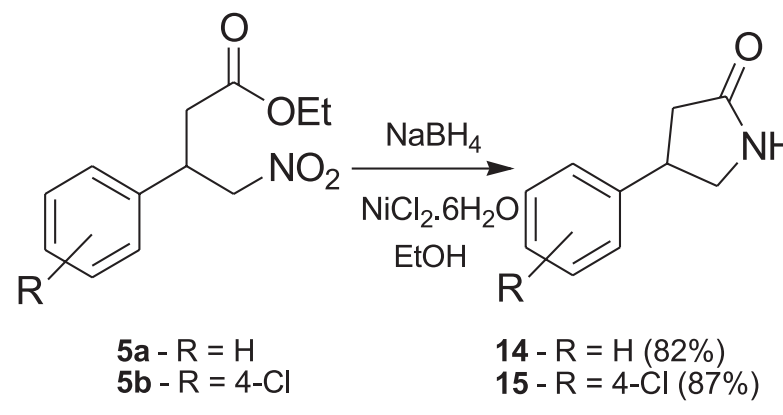<smiles>[R]c1ccc(C(CN)CC(=O)O)cc1</smiles>

$16-\mathrm{R}=\mathrm{H}$, Phenibut, $88 \%$ $17-\mathrm{R}=4-\mathrm{Cl}$, Baclofen, $89 \%$

Scheme 8. Synthesis of Phenibut (16) and Baclofen (17).

with a $\mathrm{m} / \mathrm{z}$ scan range of 70-1000. Samples were directly infused into the ESI source at flow rates of $15 \mu \mathrm{L} \mathrm{min}^{-1}$ by means of a microsyringe pump.

\section{General procedure for the preparation of the $\mathrm{HT}$ and $\mathrm{HT}_{\text {[Cal.] }}$ catalyst ${ }^{44}$}

Hydrotalcite (HT, Mg/Al ratio 3:1) was synthesized by a co-precipitation method at ambient conditions under variable $\mathrm{pH}$ values. An aqueous solution $(50 \mathrm{~mL})$ containing $\mathrm{Mg}\left(\mathrm{NO}_{3}\right)_{2} \cdot 6 \mathrm{H}_{2} \mathrm{O}(0.09 \mathrm{~mol})$ and $\mathrm{Al}\left(\mathrm{NO}_{3}\right)_{3} \cdot 9 \mathrm{H}_{2} \mathrm{O}$ $(0.03 \mathrm{~mol})$ was slowly added $(2 \mathrm{~h})$ to a second solution $(100 \mathrm{~mL})$ containing $\mathrm{NaHCO}_{3}(0.25 \mathrm{~mol})$ under vigorous stirring at $80{ }^{\circ} \mathrm{C}$, and it was continuously stirred for additional $2 \mathrm{~h}$ at the same temperature. The precipitate formed was filtered and washed with deionized water until the $\mathrm{pH}$ of the filtrate was 7 . Then, the precipitate was dried in the oven at $105^{\circ} \mathrm{C}$ for $12 \mathrm{~h}$, and finally, it was macerated to produce a white-powder. The obtained HT powder was calcined in a conventional oven at $450{ }^{\circ} \mathrm{C}$ for $4 \mathrm{~h}$ to afford a new white powder that was called hydrotalcite calcined. The specific surface area (BET multipoint technique) of $\mathrm{HT}_{\text {[Calc.] }}$ was obtained from samples previously degassed at $120{ }^{\circ} \mathrm{C}$ under vacuum for $10 \mathrm{~h}$ by $\mathrm{N}_{2}$ adsorption desorption isotherms using a Tristar $3020 \mathrm{Kr}$ Micromeritics equipment. The specific surface area was estimated as $130 \pm 5 \mathrm{~m}^{2} \mathrm{~g}^{-1}$. The X-ray diffraction (XRD) measurements were carried out using a Siemens D-500 powder diffractometer. Data were collected with $\mathrm{Cu} \mathrm{K} \alpha$ radiation with a wavelength of 
$0.15418 \mathrm{~nm}$. Compared to typical patterns, the results show the transformation of HT into $\mathrm{HT}_{[\text {Calc. }]}{ }^{12}$

General procedure for the multicomponent synthesis of $\gamma$-nitroesters 5a-r

A mixture of aromatic aldehydes $\mathbf{2 a - j}$ (1 mmol), Meldrum's acid (1, $1.0 \mathrm{mmol})$, nitromethane (3, $5.0 \mathrm{mmol})$ and hydrotalcite $(0.05 \mathrm{~g})$ was stirred at reflux for $24 \mathrm{~h}$ in an alcoholic solvent $(1.0 \mathrm{~mL})$. Afterwards, the resulting mixture was filtered through Celite using $\mathrm{CH}_{2} \mathrm{Cl}_{2}$ as the eluent. The filtrate was concentrated and purified by column chromatography on silica gel using a gradient of hexanes and ethyl acetate as the eluent to give the $\gamma$-nitroesters 5a-r.

\section{Ethyl 4-nitro-3-phenylbutanoate (5a) ${ }^{36}$}

Yield $24.0 \mathrm{mg}, 85 \%$ (hexane/ethyl acetate 70:30); brown oil; ${ }^{1} \mathrm{H}$ NMR $\left(300 \mathrm{MHz}, \mathrm{CDCl}_{3}\right) \delta 1.17$ (t, 3H, J 7.5 Hz), 2.76 (d, 2H, J 6.0 Hz), 3.99 (q, 1H, J $7.5 \mathrm{~Hz}), 4.08$ (q, 2H, $J 7.5 \mathrm{~Hz}$ ), 4.63 (dd, 1H, $J 12.0$ and $9.0 \mathrm{~Hz}$ ), 4.73 (dd, $1 \mathrm{H}$, $J 12.0$ and $7.5 \mathrm{~Hz}), 7.22-7.36(\mathrm{~m}, 5 \mathrm{H}) ;{ }^{13} \mathrm{C} \mathrm{NMR}(75 \mathrm{MHz}$, $\left.\mathrm{CDCl}_{3}\right) \delta 14.0,37.7,40.1,60.8,79.4,127.3$ (2C), 127.9, 128.9 (2C), 138.2, 170.5; IR $v_{\max } / \mathrm{cm}^{-1} 3031,2985,1723$, 1547, 1453, 1430, 1376, 1224, 1168, 852, 767, 734, 698.

\section{Ethyl 3-(4-clorophenyl)-4-nitrobutanoate (5b) ${ }^{36}$}

Yield $22.5 \mathrm{mg}, 83 \%$ (hexane/ethyl acetate 70:30); brown oil; ${ }^{1} \mathrm{H}$ NMR (300 MHz, $\left.\mathrm{CDCl}_{3}\right) \delta 1.18$ (t, 3H, J 7.5 Hz), 2.69 (dd, 1H, $J 15.0$ and $9.0 \mathrm{~Hz}$ ), $2.76(\mathrm{dd}, 1 \mathrm{H}, J 15.0$ and $6.0 \mathrm{~Hz}), 3.97$ (q, 1H, J 6.0 Hz), 4.08 (q, 1H, J 7.5 Hz), 4.60 (dd, $1 \mathrm{H}, J 15.0$ and $9.0 \mathrm{~Hz}), 4.72(\mathrm{dd}, 1 \mathrm{H}, J 12.0$ and $6.0 \mathrm{~Hz}$ ), $7.17(\mathrm{~d}, 2 \mathrm{H}, J 9.0 \mathrm{~Hz}), 7.31(\mathrm{~d}, 2 \mathrm{H}, J 9.0 \mathrm{~Hz}) ;{ }^{13} \mathrm{C} \mathrm{NMR}$ $\left(75 \mathrm{MHz}, \mathrm{CDCl}_{3}\right) \delta 13.9,37.4,39.5,60.9,79.0,128.7$ (2C), 129.0 (2C), 133.6, 136.7, 170.3; IR $v_{\max } / \mathrm{cm}^{-1} 2923,2915$, 1724, 1538, 1484, 1368, 1182, 1097, 1012, 826, 734, 717.

\section{Ethyl 3-(4-bromophenyl)-4-nitrobutanoate (5c) ${ }^{36}$}

Yield $27.8 \mathrm{mg}, 88 \%$ (hexane/ethyl acetate 70:30); brown oil; ${ }^{1} \mathrm{H}$ NMR $\left(300 \mathrm{MHz}, \mathrm{CDCl}_{3}\right) \delta 1.17(\mathrm{t}, 3 \mathrm{H}, J 7.5 \mathrm{~Hz})$, $2.70(\mathrm{~m}, 1 \mathrm{H}), 3.95(\mathrm{~m}, 1 \mathrm{H}), 4.07(\mathrm{~m}, 2 \mathrm{~Hz}), 4.60(\mathrm{dd}, 1 \mathrm{H}$, $J 12.0$ and $9.0 \mathrm{~Hz}$ ), 4.71 (dd, $1 \mathrm{H}, J 15.0$ and $6.0 \mathrm{~Hz}), 7.12$ $(\mathrm{d}, 2 \mathrm{H}, J 6.0 \mathrm{~Hz}), 7.45$ (d, 2H, J 6.0 Hz); ${ }^{13} \mathrm{C} \mathrm{NMR}(75 \mathrm{MHz}$, $\left.\mathrm{CDCl}_{3}\right) \delta 14.0,37.4,39.6,61.0,79.0,121.9,129.0$ (2C), 132.0 (2C), 137.2, 170.3; IR $v_{\max } / \mathrm{cm}^{-1} 2984,1726,1545$, 1485, 1357, 1161, 1070, 1010, 829, 726, 715.

\section{Ethyl 3-(4-fluorophenyl)-4-nitrobutanoate (5d) ${ }^{36}$}

Yield $23 \mathrm{mg}, 90 \%$ (hexane/ethyl acetate 70:30); brown oil; ${ }^{1} \mathrm{H}$ NMR (300 MHz, $\left.\mathrm{CDCl}_{3}\right) \delta 1.17$ (t, 3H, J 7.5 Hz), 2.72 (m, 2Hz), 3.96 (m, 1H), 4.06 (q, 2H, J $6.0 \mathrm{~Hz}), 4.60$ (dd, 1H, $J 12.0$ and $9.0 \mathrm{~Hz}), 4.72(\mathrm{dd}, 1 \mathrm{H}, J 12.0$ and $6.0 \mathrm{~Hz}), 7.17$ (d, 2H, J 9.0 Hz), 7.29 (d, 2H, J 9.0 Hz); ${ }^{13} \mathrm{C} \mathrm{NMR}\left(75 \mathrm{MHz}, \mathrm{CDCl}_{3}\right) \delta 14.0,37.7,39.5,60.9,79.3$, 115.9 (2C, d, J $22 \mathrm{~Hz}), 129.0$ (2C, d, J 7.7 Hz), 133.9 (d, $J 4.4 \mathrm{~Hz}$ ), 162.2 (d, J 246.6 Hz), 170.4; IR $v_{\max } / \mathrm{cm}^{-1} 2985$, 2931, 1725, 1599, 1552, 1508, 1429, 1370, 1228, 1161, 1098, 1019, 830, 781, 768, 720, 702.

\section{Ethyl 3-(4-cyanophenyl)-4-nitrobutanoate (5e) $)^{36}$}

Yield $21.0 \mathrm{mg}, 80 \%$ (hexane/ethyl acetate 70:30); yellow pale oil; ${ }^{1} \mathrm{H} \mathrm{NMR}\left(300 \mathrm{MHz}, \mathrm{CDCl}_{3}\right) \delta 1.19(\mathrm{t}, 3 \mathrm{H}$, $J 6.0 \mathrm{~Hz}), 2.77$ (m, 2H), 4.01-4.13 (m, 3H), 4.65 (dd, 1H, $J 15.0$ and $9.0 \mathrm{~Hz}$ ), 4.77 (dd, $1 \mathrm{H}, J 12.0$ and $6.0 \mathrm{~Hz}), 7.38$ $(\mathrm{d}, 2 \mathrm{H}, J 6.0 \mathrm{~Hz}), 7.66(\mathrm{~d}, 2 \mathrm{H}, J 9.0 \mathrm{~Hz}) ;{ }^{13} \mathrm{C} \mathrm{NMR}(75 \mathrm{MHz}$, $\left.\mathrm{CDCl}_{3}\right) \delta 14.0,37.1,40.0,61.2,78.5,112.1,118.2,128.3$ (2C), 132.8 (2C), 143.6, 169.9; IR $v_{\max } / \mathrm{cm}^{-1} 2982,2934$, 2230, 1729, 1610, 1548, 1378, 1226, 1158, 1090, 1018, 842, 784, 763, 718, 694.

\section{Ethyl 3-(4-methoxyphenyl)-4-nitrobutanoate (5f) ${ }^{36}$}

Yield $18.0 \mathrm{mg}, 70 \%$ (hexane/ethyl acetate 70:30); brown oil; ${ }^{1} \mathrm{H}$ NMR $\left(300 \mathrm{MHz}, \mathrm{CDCl}_{3}\right) \delta 1.18(\mathrm{t}, 3 \mathrm{H}, J 6.0 \mathrm{~Hz})$, $2.74(\mathrm{~m}, 2 \mathrm{H}), 3.78(\mathrm{~s}, 3 \mathrm{H}), 3.94(\mathrm{~m}, 1 \mathrm{H}), 4.08(\mathrm{q}, 2 \mathrm{H}$, $J 7.5 \mathrm{~Hz}), 4.59$ (dd, 1H, $J 12.0$ and $6.0 \mathrm{~Hz}), 4.70(\mathrm{dd}, 1 \mathrm{H}$, $J 12.0$ and $6.0 \mathrm{~Hz}), 6.85(\mathrm{~d}, 2 \mathrm{H}, J 9.0 \mathrm{~Hz}), 7.14(\mathrm{~d}, 2 \mathrm{H}$, $J 9.0 \mathrm{~Hz}) ;{ }^{13} \mathrm{C} \mathrm{NMR}\left(75 \mathrm{MHz}, \mathrm{CDCl}_{3}\right) \delta 14.0,37.9,39.5$, 55.2, 60.9, 79.7, 114.3 (2C), 128.4 (2C), 130.1, 159.1, 170.6; IR $v_{\max } / \mathrm{cm}^{-1} 2969,2833,1718,1597,1545,1500$, 1470, 1432, 1364, 1251, 1176, 1018, 829, 694.

\section{Ethyl 3-(3,4-dimethoxyphenyl)-4-nitrobutanoate (5g) (36 $^{36}$}

Yield $22.3 \mathrm{mg}, 75 \%$ (hexane/ethyl acetate 70:30); brown oil; ${ }^{1} \mathrm{H}$ NMR (300 MHz, $\left.\mathrm{CDCl}_{3}\right) \delta 1.19$ (t, 3H, J 7.5 Hz), 2.74 (d, 2H, J 9.0 Hz), 3.86 (s, 3H), 3.88 (s, 3H), 3.93 $(\mathrm{m}, 1 \mathrm{H}), 4.09(\mathrm{q}, 2 \mathrm{H}, J 6.0 \mathrm{~Hz}), 4.61(\mathrm{dd}, 1 \mathrm{H}, J 12.0$ and $9.0 \mathrm{~Hz}), 4.71(\mathrm{dd}, 1 \mathrm{H}, J 12.0$ and $6.0 \mathrm{~Hz}), 6.72-6.84(\mathrm{~m}$, $3 \mathrm{H}) ;{ }^{13} \mathrm{C} \mathrm{NMR}\left(75 \mathrm{MHz}, \mathrm{CDCl}_{3}\right) \delta 14.0,37.8,39.9,55.8$, 55.9, 60.9, 79.6, 110.6, 111.4, 119.2, 130.6, 148.6, 149.1, 170.6; IR $v_{\max } / \mathrm{cm}^{-1} 2969,2833,1718,1597,1545,1500$, 1470, 1432, 1364, 1251, 1176, 1018, 829, 694.

\section{Ethyl 4-nitro-3-(3,4,5-trimethoxyphenyl)butanoate (5h) ${ }^{36}$}

Yield $31.0 \mathrm{mg}$, 95\% (hexane/ethyl acetate 70:30); yellow solid; m.p. $91-93{ }^{\circ} \mathrm{C} ;{ }^{1} \mathrm{H} \mathrm{NMR}\left(300 \mathrm{MHz}, \mathrm{CDCl}_{3}\right) \delta$ 1.20 (t, 3H, J 7.5 Hz), 2.75 (d, 2H, J $7.5 \mathrm{~Hz}), 3.82$ (s, 3H), 3.85 (s, 6H), 3.90 (m, 1H), 4.11 (q, 2H, J 7.0 Hz), 4.60$4.78(\mathrm{~m}, 2 \mathrm{H}), 6.42(\mathrm{~s}, 2 \mathrm{H}) ;{ }^{13} \mathrm{C} \mathrm{NMR}\left(75 \mathrm{MHz}, \mathrm{CDCl}_{3}\right) \delta$ 14.1, 37.8, 40.4, 56.1, 60.8, 61.0, 79.4, 104.2, 104.3, 133.9, $137.5,153.5$ (2C), 170.6; IR $v_{\max } / \mathrm{cm}^{-1} 2946,2830,1724$, 1591, 1545, 1462, 1421, 1396, 1353, 1319, 1270, 1251, $1217,1176,1129,995,905,841,773,731$. 
Ethyl 4-nitro-3-(thiophen-2-yl)butanoate (5i) ${ }^{36}$

Yield $23.0 \mathrm{mg}, 85 \%$ (hexane/ethyl acetate 80:20); brown oil; ${ }^{1} \mathrm{H}$ NMR (300 MHz, $\left.\mathrm{CDCl}_{3}\right) \delta 1.22(\mathrm{t}, 3 \mathrm{H}, J 7.5 \mathrm{~Hz})$, 2.81 (d, 2H, J 6.0 Hz), 4.12 (q, 2H, J 7.5 Hz), 4.30 (m, 1H), $4.65(\mathrm{dd}, 1 \mathrm{H}, J 12.0$ and $9.0 \mathrm{~Hz}), 4.76(\mathrm{dd}, 1 \mathrm{H}, J 12.0$ and $6.0 \mathrm{~Hz}), 6.93$ (m, 2H), $7.22(\mathrm{~m}, 1 \mathrm{H}) ;{ }^{13} \mathrm{C} \mathrm{NMR}(75 \mathrm{MHz}$, $\left.\mathrm{CDCl}_{3}\right) \delta 13.9,35.5,38.4,60.9,79.5,124.7,125.4,126.9$, 140.8, 170.2; IR $v_{\max } / \mathrm{cm}^{-1} 3108,2985,1708,1545,1432$, 1382, 1203, 1176, 1024, 853, 701 .

\section{Ethyl 4-nitro-3-(thiophen-3-yl)butanoate (5j)}

Yield $20.0 \mathrm{mg}, 83 \%$ (hexane/ethyl acetate 80:20); rose oil; ${ }^{1} \mathrm{H}$ NMR (300 MHz, $\left.\mathrm{CDCl}_{3}\right) \delta 1.20$ (t, 3H, J 6.0 Hz), $2.75(\mathrm{~d}, 2 \mathrm{H}, J 6.0 \mathrm{~Hz}), 4.11(\mathrm{q}, 2 \mathrm{H}, J 6.0 \mathrm{~Hz}), 4.11-4.14$ $(\mathrm{m}, 1 \mathrm{H}), 4.62(\mathrm{dd}, 1 \mathrm{H}, J 10.5$ and $6.0 \mathrm{~Hz}), 4.72(\mathrm{dd}, 1 \mathrm{H}$, $J 9.0$ and $6.0 \mathrm{~Hz}), 6.98(\mathrm{~d}, 1 \mathrm{H}, J 6.0 \mathrm{~Hz}), 7.13(\mathrm{~s}, 1 \mathrm{H}), 7.32$ $(\mathrm{m}, 1 \mathrm{H}) ;{ }^{13} \mathrm{C} \mathrm{NMR}\left(75 \mathrm{MHz}, \mathrm{CDCl}_{3}\right) \delta 13.9,35.6,37.5$, 60.8, 79.0, 122.1 (2C), 126.0 (2C), 126.6, 138.8, 170.5; IR $v_{\max } / \mathrm{cm}^{-1} 3100,2982,2925,1724,1553,1368,1171$, 1024, 791; elemental analysis calculated for $\mathrm{C}_{10} \mathrm{H}_{13} \mathrm{NO}_{4} \mathrm{~S}$ : C 49.37, H 5.39, N 5.76; found: C 49.77, H 5.08, N 5.78 .

\section{Methyl 4-nitro-3-phenylbutanoate $(5 \mathrm{~m})^{45}$}

Yield $18.7 \mathrm{mg}, 84 \%$ (hexane/ethyl acetate 75:25); brown oil; ${ }^{1} \mathrm{H}$ NMR $\left(300 \mathrm{MHz}, \mathrm{CDCl}_{3}\right) \delta 2.70$ (d, 2H, $J 9.0 \mathrm{~Hz}$ ), 3.56 (s, 3H), 3.92 (m, 1H), 4.56 (dd, 1H, J 12.0 and $9.0 \mathrm{~Hz}), 4.67(\mathrm{dd}, 1 \mathrm{H}, J 12.0$ and $6.0 \mathrm{~Hz}), 7.21(\mathrm{~m}$, $5 \mathrm{H}) ;{ }^{13} \mathrm{C} \mathrm{NMR}\left(75 \mathrm{MHz}, \mathrm{CDCl}_{3}\right) \delta 37.4,40.2,51.8,79.3$, 127.1 (2C), 127.9, 128.9 (2C), 138.2, 171.0; IR v $v_{\max } / \mathrm{cm}^{-1}$ 2923, 2846, 1731, 1545, 1430, 1375, 1260, 1159, 1089, $1004,870,764,702$.

\section{Methyl 3-(4-methoxyphenyl)-4-nitrobutanoate (5n $)^{45}$}

Yield $18.2 \mathrm{mg}, 72 \%$ (hexane/ethyl acetate 80:20); yellow solid; m.p. $84-86{ }^{\circ} \mathrm{C}$; ${ }^{1} \mathrm{H}$ NMR $\left(300 \mathrm{MHz}, \mathrm{CDCl}_{3}\right)$ $\delta 2.74(\mathrm{~d}, 2 \mathrm{H}, J 7.5 \mathrm{~Hz}), 3.62$ (s, 3H), 3.79 (s, 3H), 3.93 (q, $1 \mathrm{H}, J 12 \mathrm{~Hz}), 4.59$ (dd, $1 \mathrm{H}, J 12.0$ and $9.0 \mathrm{~Hz}), 4.70$ (dd, $1 \mathrm{H}, J 12.0$ and $6.0 \mathrm{~Hz}), 6.85(\mathrm{~d}, 2 \mathrm{H}, J 9.0 \mathrm{~Hz}), 7.14(\mathrm{~d}, 2 \mathrm{H}$, $J 9.0 \mathrm{~Hz}) ;{ }^{13} \mathrm{C} \mathrm{NMR}\left(75 \mathrm{MHz}, \mathrm{CDCl}_{3}\right) \delta 37.6,39.4,51.8$, 55.3, 79.6, 114.3 (2C), 128.3 (2C), 130.0, 159.1, 171.1; IR $v_{\max } / \mathrm{cm}^{-1} 2957,2834,1733,1614,1548,1514,1439$, 1270, 1268, 1179, 1092, 890, 750 .

\section{Isopropyl 4-nitro-3-phenylbutanoate (50)}

Yield $18.8 \mathrm{mg}, 75 \%$ (hexane/ethyl acetate 75:25); yellow oil; ${ }^{1} \mathrm{H} \mathrm{NMR}\left(300 \mathrm{MHz}, \mathrm{CDCl}_{3}\right) \delta 1.12(\mathrm{~d}, 3 \mathrm{H}$, $J 6.4 \mathrm{~Hz}$ ), 1.14 (d, 3H, J 6.4 Hz), 2.73 (d, 2H, J 7.6 Hz), 3.92-4.02 (m, 1H), 4.63 (dd, 1H, J 12.3 and 7.6 Hz), 4.72 (dd, $1 \mathrm{H}, J 12.3$ and 7.0 Hz), 4.87-4.97 (m, 1H), 7.21-7.36 $(\mathrm{m}, 5 \mathrm{H}) ;{ }^{13} \mathrm{C} \mathrm{NMR}\left(75 \mathrm{MHz}, \mathrm{CDCl}_{3}\right) \delta 21.6$ (2C), 38.0,
40.3, 68.3, 79.5, 127.3 (2C), 127.9, 128.9 (2C), 138.2, 170.0; IR $v_{\max } / \mathrm{cm}^{-1} 3031,2985,2923,1731,1545,1461$, 1432, 1378, 1270, 1197, 1104, 963, 898, 825, 760, 699; HRMS calculated for $\left[\mathrm{C}_{13} \mathrm{H}_{17} \mathrm{NO}_{4}-\mathrm{HNO}_{2}\right]$ : 204.1151; found: 204.1197.

Isopropyl 3-(4-methoxyphenyl)-4-nitrobutanoate (5p)

Yield $18.0 \mathrm{mg}, 64 \%$ (hexane/ethyl acetate 70:30); yellow oil; ${ }^{1} \mathrm{H}$ NMR (300 MHz, $\left.\mathrm{CDCl}_{3}\right) \delta 1.14(\mathrm{~m}, 6 \mathrm{H})$, $2.69(\mathrm{~m}, 2 \mathrm{H}), 3.78$ (s, 3H), $3.92(\mathrm{~m}, 1 \mathrm{H}), 4.58$ (dd, 1H, $J 12.3$ and $8.1 \mathrm{~Hz}), 4.68(\mathrm{dd}, 1 \mathrm{H}, J 12.4$ and $6.9 \mathrm{~Hz})$, 4.93 (h, 1H, J $6.3 \mathrm{~Hz}), 6.85$ (d, 2H, J $9 \mathrm{~Hz}), 7.14$ (d, 2H, $J 8.7 \mathrm{~Hz}) ;{ }^{13} \mathrm{C}$ NMR $\left(75 \mathrm{MHz}, \mathrm{CDCl}_{3}\right.$ ) $\delta 21.6(2 \mathrm{C}), 38.1$, 39.6, 55.2, 68.3, 79.7, 114.3 (2C), 128.4 (2C), 130.0, 159.1, 170.1; IR $v_{\max } / \mathrm{cm}^{-1} 2982,2934,1729,1615,1553,1515$, 1378, 1256, 1347, 1178, 985, 785; HRMS calculated for $\left[\mathrm{C}_{14} \mathrm{H}_{19} \mathrm{NO}_{5}+\mathrm{Na}\right]$ : 304.1161; found: 304.1163 .

\section{Butyl 3-(4-methoxyphenyl)-4-nitrobutanoate (5q)}

Yield $14.6 \mathrm{mg}, 55 \%$ (hexane/ethyl acetate 90:10); yellow oil; ${ }^{1} \mathrm{H}$ NMR $\left(300 \mathrm{MHz}, \mathrm{CDCl}_{3}\right) \delta 0.88(\mathrm{t}, 3 \mathrm{H}$, $J 7.5 \mathrm{~Hz}), 1.27(\mathrm{~m}, 2 \mathrm{H}), 1.51(\mathrm{~m}, 2 \mathrm{H}), 2.73(\mathrm{~d}, 2 \mathrm{H}$, $J 7.6 \mathrm{~Hz}), 3.78(\mathrm{~s}, 3 \mathrm{H}), 3.93(\mathrm{~m}, 1 \mathrm{H}), 4.02(\mathrm{t}, 2 \mathrm{H}, J 6.6 \mathrm{~Hz})$, $4.59(\mathrm{dd}, 1 \mathrm{H}, J 12.4$ and $8.1 \mathrm{~Hz}), 4.69$ (dd, $1 \mathrm{H}, J 12.3$ and $7.2 \mathrm{~Hz}), 6.86$ (d, 2H, J 6.6 Hz), 7.14 (d, 2H, J 6.6 Hz); ${ }^{13} \mathrm{C} \mathrm{NMR}\left(75 \mathrm{MHz}, \mathrm{CDCl}_{3}\right) \delta 13.6,19.0,30.5,37.9,39.5$, 55.2, 64.7, 79.7, 114.3 (2C), 128.3 (2C), 130.0, 159.2, 170.7; IR $v_{\max } / \mathrm{cm}^{-1} 2958,2934,1729,1553,1615,1553$, 1510, 1382, 1251, 1175, 984, 680; HRMS calculated for $\left[\mathrm{C}_{15} \mathrm{H}_{21} \mathrm{NO}_{5}+\mathrm{Na}\right]: 318.1317$; found: 318.1325 .

\section{tert-Butyl 4-nitro-3-phenylbutanoate (5r)}

Yield $15.3 \mathrm{mg}, 58 \%$ (hexane/ethyl acetate 85:25); yellow oil; ${ }^{1} \mathrm{H}$ NMR $\left(300 \mathrm{MHz}, \mathrm{CDCl}_{3}\right) \delta 1.33(\mathrm{~s}, 9 \mathrm{H}), 2.67$ (dd, 2H, J 7.6 and $2.9 \mathrm{~Hz}), 1.14$ (d, 3H, J 6.4 Hz), 2.73 (d, $2 \mathrm{H}, J 7.6 \mathrm{~Hz}), 3.92-4.02(\mathrm{~m}, 1 \mathrm{H}), 4.63(\mathrm{dd}, 1 \mathrm{H}, J 12.3$ and $7.6 \mathrm{~Hz}), 4.72(\mathrm{dd}, 1 \mathrm{H}, J 12.3$ and $7.0 \mathrm{~Hz}), 4.87-4.97(\mathrm{~m}$, 1H), 7.21-7.36 (m, 5H); ${ }^{13} \mathrm{C} \mathrm{NMR}\left(75 \mathrm{MHz}, \mathrm{CDCl}_{3}\right) \delta 27.8$ (3C), 38.8, 40.5, 79.6, 81.3, 127.4 (2C), 127.9 (2C), 128.9, 138.3, 169.7; IR $v_{\max } / \mathrm{cm}^{-1} 3066,2923,1714,1537,1455$, 1435, 1364, 1271, 1242, 1149, 842, 767, 724, 692; HRMS calculated for $\left[\mathrm{C}_{18} \mathrm{H}_{28} \mathrm{NO}_{5}\right]$ : 192.0655; found: 192.0645; elemental analysis calculated for $\mathrm{C}_{18} \mathrm{H}_{28} \mathrm{NO}_{5}$ : C 63.38, $\mathrm{H}$ 7.22, N 5.28; found: C 64.02, H 6.94, N 5.13.

General procedure for the synthesis of $\gamma$-nitroesters $5 \mathbf{s}-\mathbf{u}$

A mixture of adduct $6 \mathbf{a}(1.0 \mathrm{mmol}), \mathrm{HT}(0.05 \mathrm{~g})$ and benzylic, allylic or propargyl alcohol $(1.0 \mathrm{mmol})$ was submitted to reaction in the presence of 3.0-5.0 mL of $\mathrm{MeCN}$ under reflux for $24 \mathrm{~h}$. Afterwards, the resulting 
mixture was filtered through Celite using $\mathrm{CH}_{2} \mathrm{Cl}_{2}$ as the eluent. The filtrate was concentrated and purified by column chromatography on silica gel using a gradient of hexanes and ethyl acetate as the eluent to give the $\gamma$-nitroesters $\mathbf{5 s - u}$.

\section{Benzyl 4-nitro-3-phenylbutanoate (5s)}

Yield $60 \%$ (hexane/ethyl acetate 70:30); brown oil; ${ }^{1} \mathrm{H} \mathrm{NMR}\left(300 \mathrm{MHz}, \mathrm{CDCl}_{3}\right) \delta 2.85(\mathrm{~d}, 2 \mathrm{H}, J 6.0 \mathrm{~Hz}), 4.03$ (quint, $1 \mathrm{H}, J 6.0 \mathrm{~Hz}), 4.65(\mathrm{dd}, 1 \mathrm{H}, J 12.0$ and $6.0 \mathrm{~Hz}$ ), $4.73(\mathrm{dd}, 1 \mathrm{H}, J 12.0$ and $6.0 \mathrm{~Hz}), 5.09$ (s, 2H), 7.22-7.37 $(\mathrm{m}, 10 \mathrm{H}) ;{ }^{13} \mathrm{C} \mathrm{NMR}\left(75 \mathrm{MHz}, \mathrm{CDCl}_{3}\right) \delta 37.6,40.1,66.7$, 79.3, 127.3 (2C), 128.0, 128.2 (2C), 128.3, 128.5 (2C), 129.0 (2C), 135.3, 138.0, 170.4; IR $v_{\max } / \mathrm{cm}^{-1} 3025,2920$, 1738, 1544, 1381, 1211, 1179, 1009, 726, 702, 548, 459; elemental analysis calculated for $\mathrm{C}_{17} \mathrm{H}_{17} \mathrm{NO}_{4}: \mathrm{C} 68.21, \mathrm{H}$ 5.72, N 4.68; found: C 67.55, H 5.72, N 4.41.

\section{Allyl 4-nitro-3-phenylbutanoate (5t)}

Yield 75\% (hexane/ethyl acetate 70:30); brown oil; ${ }^{1} \mathrm{H} \mathrm{NMR}\left(300 \mathrm{MHz}, \mathrm{CDCl}_{3}\right) \delta 2.73(\mathrm{~d}, 2 \mathrm{H}, J 9.0 \mathrm{~Hz}), 3.92$ (quint, $1 \mathrm{H}, J 6.0 \mathrm{~Hz}), 4.45(\mathrm{~m}, 2 \mathrm{H}), 4.56(\mathrm{dd}, 1 \mathrm{H}, J 15.0$ and $9.0 \mathrm{~Hz}), 4.65(\mathrm{dd}, 1 \mathrm{H}, J 12.0$ and $9.0 \mathrm{~Hz}), 5.11-5.19(\mathrm{~m}$, $2 \mathrm{H}), 5.73(\mathrm{~m}, 1 \mathrm{H}), 7.14-7.29(\mathrm{~m}, 5 \mathrm{H}) ;{ }^{13} \mathrm{C}$ NMR $(75 \mathrm{MHz}$, $\left.\mathrm{CDCl}_{3}\right) \delta 37.5,40.0,65.5,79.3,118.5,127.3,127.9$ (2C), 129.0 (2C), 131.5, 138.1, 170.2; IR $v_{\text {max }} / \mathrm{cm}^{-1} 3025,2928$, 1730, 1551, 1374, 1163, 985, 936, 768, 693; elemental analysis calculated for $\mathrm{C}_{13} \mathrm{H}_{15} \mathrm{NO}_{4}$ : $\mathrm{C} 62.64, \mathrm{H} 6.07, \mathrm{~N} 5.62$; found: C 62.34, H 6.10, N 5.23.

\section{Prop-2-ynyl 4-nitro-3-phenylbutanoate (5u)}

Yield 65\% (hexane/ethyl acetate 80:20); pale yellow oil; ${ }^{1} \mathrm{H}$ NMR (300 MHz, $\left.\mathrm{CDCl}_{3}\right) \delta 2.39$ (t, 1H, J $3.0 \mathrm{~Hz}$ ), 2.76 (d, $2 \mathrm{H} J 6.0 \mathrm{~Hz}$ ), 3.93 (quint, $1 \mathrm{H}, J 7.5 \mathrm{~Hz}), 4.62(\mathrm{~m}, 4 \mathrm{H})$, 7.14-7.30 (m, 5H); ${ }^{13} \mathrm{C} \mathrm{NMR}\left(75 \mathrm{MHz}, \mathrm{CDCl}_{3}\right) \delta 37.3,40.0$, 52.3, 75.2, 77.0, 79.2, 127.3 (2C), 128.1, 129.0 (2C), 137.9, 169.8, IR $v_{\max } / \mathrm{cm}^{-1} 3292,3033,2928,2126,1738,1551$, 1374, 1155, 985, 766, 693, 637, 532; elemental analysis calculated for $\mathrm{C}_{13} \mathrm{H}_{13} \mathrm{NO}_{4}$ : C 63.15, H 5.30, N 5.67; found: C 63.11, H 5.25, N 5.43.

\section{General procedure for the synthesis of Michael adduct $\mathbf{6 a}$}

Nitrostyrene (1 mmol), Meldrum's acid $(1.1 \mathrm{mmol})$ and $\mathrm{Et}_{3} \mathrm{~N}$ (1.0 mmol) in $\mathrm{CH}_{2} \mathrm{Cl}_{2}$ were added into a round bottom flask. The mixture was submitted to magnetic stirred at room temperature overnight. The crude product was diluted in $5.0 \mathrm{~mL}$ of $\mathrm{CH}_{2} \mathrm{Cl}_{2}$ and washed with $\mathrm{HCl}$ $(5 \%, 3 \times 5.0 \mathrm{~mL})$. The organic phases were dried with $\mathrm{MgSO}_{4}$, filtered and evaporated under vacuum afford adduct $6 \mathbf{a}$.
2,2-Dimethyl-5-(2-nitro-1-phenylethyl)-1,3-dioxane-4,6dione $(\mathbf{6 a})^{46}$

Yield $27.8 \mathrm{mg}$, 95\%; viscous yellow oil; ${ }^{1} \mathrm{H}$ NMR $\left(300 \mathrm{MHz}, \mathrm{CDCl}_{3}\right) \delta 1.39(\mathrm{~s}, 3 \mathrm{H}), 1.72(\mathrm{~s}, 3 \mathrm{H}), 4.05(\mathrm{~d}, 1 \mathrm{H}$, $J 3.3 \mathrm{~Hz}$ ), 4.65 (m, 1H), 5.03 (dd, $1 \mathrm{H}, J 14.1$ and $6.6 \mathrm{~Hz}$ ), $5.40(\mathrm{dd}, 1 \mathrm{H}, J 13.9$ and $8.7 \mathrm{~Hz}), 7.33(\mathrm{~m}, 5 \mathrm{H}) ;{ }^{13} \mathrm{C} \mathrm{NMR}$ $\left(75 \mathrm{MHz}, \mathrm{CDCl}_{3}\right) \delta$ 27.6, 28.1, 41.9, 48.5, 75.9, 105.9, 128.7, 128.8, 128.9, 129.0, 129.2, 135.1, 163.9, 164.4; IR $v_{\max } / \mathrm{cm}^{-1} 2999,2867,1781,1735,1553,1329,1310$, 1206, 1110, 758 .

General procedure for the synthesis of 5-benzylidene-2,2dimethyl-1,3-dioxane-4,6-dione (9a)

Benzaldehyde (1.0 mmol), Meldrum's acid $(1.1 \mathrm{mmol})$ and HT $(0.05 \mathrm{~g})$ in ethanol were added into a round bottom flask. The mixture was submitted to magnetic stirring at reflux for $2 \mathrm{~h}$. Afterwards, the ethanol was removed under vacuum, and the crude product was dissolved in $10.0 \mathrm{~mL}$ of $\mathrm{CH}_{2} \mathrm{Cl}_{2}$ followed by filtering through Celite. The filtrate was concentrated under vacuum to afford the benzylidene 9 a. ${ }^{47}$ Yield $22.2 \mathrm{mg}, 96 \%$; yellow solid; m.p. 84-85 ${ }^{\circ} \mathrm{C}$; ${ }^{1} \mathrm{H}$ NMR $\left(300 \mathrm{MHz}, \mathrm{CDCl}_{3}\right) \delta 1.82(\mathrm{~s}, 6 \mathrm{H}), 7.45-7.56(\mathrm{~m}, 3 \mathrm{H}), 8.06$ (d, 2H, J $9.0 \mathrm{~Hz}), 8.42$ (s, 1H); IR $v_{\max } / \mathrm{cm}^{-1} 2996,1768$, 1729, 1618, 1361, 1289, 1189, 764.

General procedure for the synthesis of $\beta$-lactams ${ }^{48}$

Nitroesters 5a-b $(1.0 \mathrm{mmol})$ and $\mathrm{NiCl}_{2} \cdot 6 \mathrm{H}_{2} \mathrm{O}$ $(10.0 \mathrm{mmol})$ dissolved in $5 \mathrm{~mL}$ of ethanol were added into a round bottom flask. The mixture was submitted to magnetic stirring in an ice bath, followed by the addition of $\mathrm{NaBH}_{4}(10.0 \mathrm{mmol})$, and then it was stirred for $2 \mathrm{~h}$ at $0{ }^{\circ} \mathrm{C}$. Afterwards, $20 \mathrm{~mL}$ of $\mathrm{NH}_{4} \mathrm{Cl}$ was added into the flask and extracted with $\mathrm{CHCl}_{3}(3 \times 20.0 \mathrm{~mL})$. The organic phases were combined, dried with $\mathrm{MgSO}_{4}$ anhydrous, filtered through Celite and evaporated under vacuum.

\section{4-Phenylpyrrolidin-2-one (14) ${ }^{48}$}

Yield $13.2 \mathrm{mg}, 82 \%$; brown oil; ${ }^{1} \mathrm{H}$ NMR (300 MHz, $\left.\mathrm{CDCl}_{3}\right) \delta 2.51(\mathrm{dd}, 1 \mathrm{H}, J 16.9$ and $8.8 \mathrm{~Hz}), 2.74(\mathrm{dd}, 1 \mathrm{H}$, $J 16.9$ and $8.8 \mathrm{~Hz}$ ), 3.43 (dd, $1 \mathrm{H}, J 9.4$ and $7.0 \mathrm{~Hz}$ ), 3.64$3.82(\mathrm{~m}, 2 \mathrm{H}), 6.90(\mathrm{~s}, 1 \mathrm{H}), 7.25-7.35(\mathrm{~m}, 5 \mathrm{H}) ;{ }^{13} \mathrm{C} \mathrm{NMR}$ $\left(75 \mathrm{MHz}, \mathrm{CDCl}_{3}\right) \delta 37.9,40.2,49.5,126.7,127.0,128.8$, 142.6, 177.8; IR $v_{\max } / \mathrm{cm}^{-1} 3240,2923,2861,1669,1496$, 1442, 1356, 1255, 1051, 742, 688, 627.

\section{4-(4-Chlorophenyl)pyrrolidin-2-one (15) ${ }^{48}$}

Yield $17.0 \mathrm{mg}$, 87\%; brown oil; ${ }^{1} \mathrm{H}$ NMR $(300 \mathrm{MHz}$, $\left.\mathrm{CDCl}_{3}\right) \delta 2.45(\mathrm{dd}, 1 \mathrm{H}, J 16.9$ and $8.8 \mathrm{~Hz}), 2.74(\mathrm{dd}, 1 \mathrm{H}$, $J 16.9$ and $8.8 \mathrm{~Hz}), 3.39$ (t, $1 \mathrm{H}, J 7.6 \mathrm{~Hz}), 3.62-3.82(\mathrm{~m}, 2 \mathrm{H})$, 
6.52 (s, 1H), 7.19 (d, 2H, J 7.0 Hz), $7.32(\mathrm{~d}, 2 \mathrm{H}, J 7.0 \mathrm{~Hz})$; ${ }^{13} \mathrm{C} \mathrm{NMR}\left(75 \mathrm{MHz}, \mathrm{CDCl}_{3}\right) \delta 29.9,39.9,49.7,128.4,129.3$, 133.2, 140.8, 177.8; IR $v_{\max } / \mathrm{cm}^{-1} 3194,2923,2840,1673$, 1485, 1259, 1089, 1006, 824, 718, 666.

General procedure for the synthesis of amino acids Phenibut and Baclofen ${ }^{49}$

Into a round bottom flask, the $\beta$-lactam $\mathbf{1 4}$ or $\mathbf{1 5}$ $(0.4 \mathrm{mmol})$ and $10 \mathrm{~mL}$ of $\mathrm{HCl}\left(6.0 \mathrm{~mol} \mathrm{~L}^{-1}\right)$ were added. The mixture was submitted to magnetic stirring at reflux for $12 \mathrm{~h}$. Afterwards, evaporation under vacuum leads to the synthesis of the $\gamma$-amino acids.

4-Amino-3-phenylbutanoic acid hydrochloride (Phenibut, 16) ${ }^{48}$

Yield $18.9 \mathrm{mg}, 88 \%$; orange solid; m.p. $188-190{ }^{\circ} \mathrm{C}$; ${ }^{1} \mathrm{H}$ NMR $\left(300 \mathrm{MHz}, \mathrm{D}_{2} \mathrm{O}\right) \delta 2.65(\mathrm{dd}, 1 \mathrm{H}, J 15.8$ and $8.8 \mathrm{~Hz}), 2.75(\mathrm{dd}, 1 \mathrm{H}, J 15.8$ and $5.3 \mathrm{~Hz}), 3.10-3.30(\mathrm{~m}$, $3 \mathrm{H}), 7.26-7.36(\mathrm{~m}, 5 \mathrm{H}) ;{ }^{13} \mathrm{C} \mathrm{NMR}\left(75 \mathrm{MHz}, \mathrm{D}_{2} \mathrm{O}\right) \delta 40.7$, $42.4,46.3,130.3,130.8,131.8,140.8,177.9 ;$ IR $v_{\max } / \mathrm{cm}^{-1}$ $3317-2567,1711,1590,1515,1485,1402,1259,1199$, 1146, 972, 860, 761, 701.

4-Amino-3-(4-chlorophenyl)butanoic acid hydrochloride $(\text { Baclofen, 17) })^{48}$

Yield $22.2 \mathrm{mg}$, 89\%; orange solid; m.p. $198-200{ }^{\circ} \mathrm{C}$; ${ }^{1} \mathrm{H}$ NMR $\left(300 \mathrm{MHz}, \mathrm{D}_{2} \mathrm{O}\right) \delta 2.73(\mathrm{dd}, 1 \mathrm{H}, J 16.4$ and $8.8 \mathrm{~Hz}), 2.86(\mathrm{dd}, 1 \mathrm{H}, J 16.4$ and $5.9 \mathrm{~Hz}), 3.20-3.48$ $(\mathrm{m}, 3 \mathrm{H}), 7.33(\mathrm{~d}, 2 \mathrm{H}, J 8.8 \mathrm{~Hz}), 7.43(\mathrm{~d}, 2 \mathrm{H}, J 8.8 \mathrm{~Hz})$; ${ }^{13} \mathrm{C} \mathrm{NMR}\left(75 \mathrm{MHz}, \mathrm{D}_{2} \mathrm{O}\right) \delta 38.4,39.6,43.8,129.4,129.6$, 133.5, 137.1, 175.5; IR $v_{\max } / \mathrm{cm}^{-1} 3279-2505,1711$, 1590, 1560, 1493, 1410, 1395, 1245, 1194, 1139, 970, 813, 760, 706 .

\section{Supplementary Information}

Supplementary information $\left({ }^{1} \mathrm{H}\right.$ NMR and ${ }^{13} \mathrm{C}$ NMR of selected compounds and powder X-ray diffraction of hydrotalcite and calcined hydrotalite) is available free of charge at http://jbcs.sbq.org.br as a PDF file.

\section{Acknowledgments}

The authors would like to acknowledge FAPERGS, CNPq (Universal No. 455791/2014-7) and CAPES for their financial support and fellowships (C. R. M. D'O.; J. C. S.; E. P. G.). Fondecyt (11130086 and 1140642), Anillo Cientifico ACT1107, PIEI-UTalca, and Chile CORFO (FCR-CSB 09CEII-6991) are greatly acknowledged.

\section{References}

1. Sutoo, D.; Akiyama, K.; Yabe, K.; Hum. Brain Mapp. 2000, 11, 93.

2. Cai, K.; Nanga, R.; Lamprou, L.; Schinstine, C.; Elliott, M.; Hariharan, R.; Epperson, N.; Neuropsychopharmacology 2012, 37, 2764.

3. Foster, A. C.; Kemp, J. A.; Curr. Opin. Pharmacol. 2006, 6, 7.

4. Touré, B. B.; Hall D. G. In Multicomponent Reactions, $1^{\text {st }}$ ed.; Zhu, J.; Bienaymé H., eds.; Wiley-VCH: Weinheim, Germany, 2005.

5. Habibi, A.; Rahmani, A.; Helv. Chim. Acta 2011, 94, 1806.

6. Dömling, A.; Wang, W.; Wang, K.; Chem. Rev. 2012, 112, 3083.

7. Dömling, A.; Chem. Rev. 2006, 106, 17.

8. Dumas, A. M.; Fillion, E.; Acc. Chem. Res. 2010, 43, 440.

9. Lipson, V. V.; Gorobets, N. Y.; Mol. Divers. 2009, 13, 399.

10. Ivanov, A. S.; Chem. Soc. Rev. 2008, 37, 789.

11. Climent, M. J.; Corma, A.; Iborra, S.; Chem. Rev. 2011, 111, 1072.

12. Wang, D.; Zhang, X.; Wei, W.; Sun, Y.; Catal. Commun. 2012, 28, 159 .

13. Wang, S. H.; Wang, Y. B.; Dai, Y. M.; Jehng, J. M.; Appl. Catal., A 2012, 439, 135.

14. Neves, A. C. B.; Calvete, M. J. F.; Pinho e Melo, T. M. V. D.; Pereira, M. M.; Eur. J. Org. Chem. 2012, 32, 6309.

15. Winter, F.; van Dillen, A. J.; Jong, K. P.; Chem. Commun. 2005, 31, 3977.

16. Ebitani, K.; Motokura, K.; Mori, K.; Mizugaki, T.; Kaneda, K.; J. Org. Chem. 2006, 71, 5440.

17. Valente, J. S.; Cortez, J. H.; Cantu, M. S.; Ferrat, G.; Salinas, E. L.; Catal. Today 2010, 150, 340.

18. Kshirsagar, S. W.; Patil, N. R.; Samant, S. D.; Tetrahedron Lett. 2010, 51, 2924.

19. Xu, Z. P.; Zhang, J.; Adebajo, M. O.; Zhang, H.; Zhou, C.; Appl. Clay Sci. 2011, 53, 139.

20. Godoi, M. N.; Costenaro, H. S.; Kramer, E.; Machado, P. S.; D’Oca, M. G. M.; Russowsky, D.; Quim. Nova 2005, 28, 1010.

21. Russowsky, D.; Benvenutti, E. V.; Roxo, G. S.; Grasel, F.; Lett. Org. Chem. 2007, 4, 39.

22. Marques, M. V.; Ruthner, M.; Fontoura, L. A. M.; Russowsky, D.; J. Braz. Chem. Soc. 2012, 23, 171.

23. Affeldt, R. F.; Benvenutti, V.; Russowsky, D.; New J. Chem. 2012, 36, 1502.

24. Costa, J. S.; Lopes, J. P. B.; Russowsky, D.; Petzhold, C. L.; Borges, A. C. A.; Ceschi, M. A.; Konrath, E.; Batassini, C.; Lunardi, P. S.; Gonçalves, C. A. S.; Eur. J. Med. Chem. 2013, 62, 556.

25. Naciuk, F. F.; Vargas, D. Z.; D’Oca, C. R. M.; Moro, C. C.; Russowsky, D.; New J. Chem. 2015, 39, 1643.

26. Prescott, H. A.; Li, Z.-J.; Kemnitz, E.; Trunschke, A.; Deutsch, J.; Lieske, H.; Auroux, A. J.; J. Catal. 2005, 234, 119. 
27. Bulbule, V. J.; Deshpande, V. H.; Velu, S.; Sudalai, A.; Sivasankar, S.; Sathe, V. T.; Tetrahedron 1999, 55, 9325.

28. Santos, L. S. In Reactive Intermediates: MS Investigations in Solution; Santos, L. S., ed.; Wiley-VCH: Weinheim, Germany, 2010.

29. Santos, L. S.; J. Braz. Chem. Soc. 2011, 22, 1827.

30. Zhao, Z.-X.; Wang, H.-Y.; Guo, Y.-L.; Curr. Org. Chem. 2011 , $15,3734$.

31. Santos, L. S.; Eur. J. Org. Chem. 2008, 235.

32. Eberlin, M. N.; Eur. J. Mass Spectrom. 2007, 13, 19.

33. Santos, L. S.; Knaack, L.; Metzger, J.; Int. J. Mass Spectrom. 2005, 246, 84.

34. Peng, H.; Yuan, Z.; Wang, H.-Y.; Guo, Y.-L.; Liu, G.; Chem. Sci. 2013, 4, 3172.

35. Shankaraiah, N.; Markandeya, N.; Srinivasulu, V.; Sreekanth, K.; Reddy, C. R.; Santos, L. S.; Kamal, A.; J. Org. Chem. 2011, 76, 7017.

36. Silva, B. V.; Violante, F. A.; Pinto, A. C.; Santos, L. S.; Rapid Commun. Mass Spectrom. 2011, 25, 423.

37. Stoddard, R. L.; Luo, J.; van ver Wal, N.; O'Rourke, N. F.; Wulff, J. E.; McIndoe, J. S.; New J. Chem. 2014, 38, 5382.

38. Oliveira, C. C.; Marques, M. V.; Godoi, M. N.; Regiani, T.; Santos, V. G.; dos Santos, E. A. F.; Eberlin, M. N.; Sá, M. M.; Correia, C. R. D.; Org. Lett. 2014, 16, 5180.
39. George, L.; Veedu, R. N.; Sheibani, H.; Taherpour, A. A.; Flammang, R.; Wentrup, C.; J. Org. Chem. 2007, 72, 1399.

40. Sytinsky, K. A.; Soldatenkov, A. T.; Prog. Neurobiol. 1978, 10, 89.

41. Mann, A.; Boulanger, T.; Brandau, B.; Durant, F.; Evrard, G.; Heaulme, M.; Desaulles, E.; Wermuth, C. G.; J. Med. Chem. 1991, 34, 1307.

42. Hynes, P. S.; Stupple, P. A.; Dixon, D. J.; Org. Lett. 2008, 10, 1389.

43. Chang, M.-Y.; Sun, P.-P.; Chen, S.-T.; Chang, N.-C.; Tetrahedron Lett. 2003, 44, 5271.

44. Rodrigues, J. C.; Costa, T. M. H.; Gallas, M. R.; Moro, C. C.; Phys. Chem. Miner. 2009, 36, 439.

45. Jensen, K. L.; Poulsen, P. H.; Donslund, B. S.; Morana, F.; Jorgensen, K. A.; Org. Lett. 2012, 14, 1516.

46. Li, J.-H.; Li, Z.-G.; Chen, Q.-G.; J. Chem. Res. 2004, 11, 758.

47. Schuster, I.; Schuster, P.; Tetrahedron 1969, 25, 199.

48. Menicagli, R.; Samaritani, S.; Tetrahedron 1996, 52, 1425.

49. Corey, E. J.; Zhang, F.-Y.; Org. Lett. 2000, 2, 4257.

Submitted: February 20, 2016

Published online: June 9, 2016

FAPERGS/CAPES has sponsored the publication of this article. 